\title{
Preconditioning-induced ischemic tolerance: a window into endogenous gearing for cerebroprotection
}

\author{
Aysan Durukan ${ }^{*}$, Turgut Tatlisumak
}

\begin{abstract}
Ischemic tolerance defines transient resistance to lethal ischemia gained by a prior sublethal noxious stimulus (i.e., preconditioning). This adaptive response is thought to be an evolutionarily conserved defense mechanism, observed in a wide variety of species. Preconditioning confers ischemic tolerance if not in all, in most organ systems, including the heart, kidney, liver, and small intestine. Since the first landmark experimental demonstration of ischemic tolerance in the gerbil brain in early 1990's, basic scientific knowledge on the mechanisms of cerebral ischemic tolerance increased substantially. Various noxious stimuli can precondition the brain, presumably through a common mechanism, genomic reprogramming. Ischemic tolerance occurs in two temporally distinct windows. Early tolerance can be achieved within minutes, but wanes also rapidly, within hours. Delayed tolerance develops in hours and lasts for days. The main mechanism involved in early tolerance is adaptation of membrane receptors, whereas gene activation with subsequent de novo protein synthesis dominates delayed tolerance. Ischemic preconditioning is associated with robust cerebroprotection in animals. In humans, transient ischemic attacks may be the clinical correlate of preconditioning leading to ischemic tolerance. Mimicking the mechanisms of this unique endogenous protection process is therefore a potential strategy for stroke prevention. Perhaps new remedies for stroke are very close, right in our cells.
\end{abstract}

\section{Review}

Surviving a sublethal noxious insult may result in a more powerful state against a following lethal insult, referring to Nietszche; "What doesn't kill you, makes you stronger." This phenomenon named as preconditioning (PC) and tolerance has been shown to exist in many organs, most extensively in the heart. The first in vivo evidence of preconditioning and tolerance in brain was provided in 1960's [1,2], but almost three decades passed without any interest from researchers on this unique phenomenon, until Kitagawa et al. opened the research era of cerebral ischemic tolerance (IT) [3].

The ability to withstand, respond to, and to cope with ongoing stress is a fundamental property of all living organisms [4]. The fate of the brain tissue after focal cerebral ischemia is determined by the degree and duration of ischemia, and even without preconditioning,

\footnotetext{
* Correspondence: aysan.durukan@hus.fi
Department of Neurology, Helsinki University Central Hospital, Helsinki,

* Correspondence: aysan.durukan@hus.fi
Department of Neurology, Helsinki University Central Hospital, Helsinki, Finland
}

() 2010 Durukan and Tatlisumak; licensee BioMed Central Ltd. This is an Open Access article distributed under the terms of the Creative Commons Attribution License (http://creativecommons.org/licenses/by/2.0), which permits unrestricted use, distribution, and reproduction in any medium, provided the original work is properly cited. by mobilizing a host of defences and counter responses to mitigate cell injury and death [5]. If the subthreshold noxious stimulus is too mild or negligibly mild, it may not induce any response, whereas if it is sufficient enough, it may serve as a PC trigger, or if it is too severe, over the threshold, may permanently injure tissues. The hallmark of PC stimulus is not being injurious. In the scenario of IT, PC stimulus primes the brain for subsequent injurious ischemic injury. Danger signal evoked in the brain by the stressing preconditioning stimulus induces complex endogenous protective mechanisms resulting to a latent protective phenotype. When the lethal ischemic insult is applied onto this latent protective phenotype, a separate set of responses are triggered that constitute ischemia-tolerant phenotype, which strikingly differs from the unprimed or unpreconditioned brain's phenotype (Figure 1). Therefore, the outcome of the brain cells is shifted by PC from death to survival. 


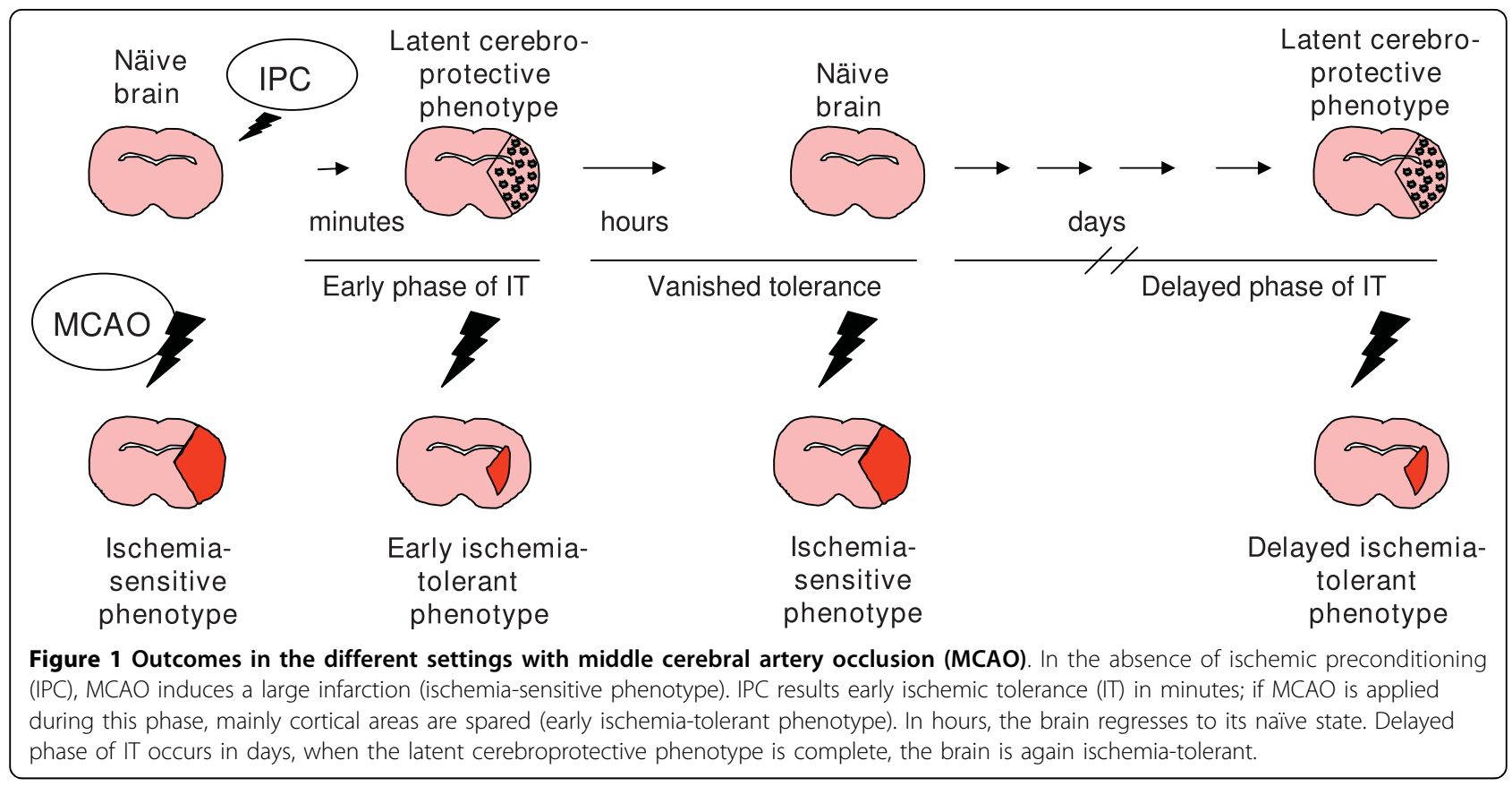

During the last years, the mechanisms underlying cerebral IT were intensely studied, and although incomplete, a vast amount of knowledge has been accumulated. The salient features of cerebral IT are presented in Table 1 . There are two temporally distinct windows of protection from ischemia afforded by PC. Early protection, i.e., early IT, has been observed in relatively fewer studies than those exposing late IT in the brain. Exploring the functional relevance of these findings has proved difficult, however.

In this review article, we first attempted to clarify the IT nomenclature. Various triggers induce cerebral IT; these are mentioned in a separate section discussing the models for IT. This variety among preconditioning triggers indicates that the downstream signaling pathways converge on some common fundamental mechanisms [5], major mechanisms are discussed briefly. A number of tools serve for examination of the efficacy of PC, chief methods are exampled. Lastly, we addressed the challenging issues of IT to encourage further research.

\section{Nomenclature}

The nomenclature used in the studies addressing the IT phenomenon is not entirely consistent. In this article, in order to keep with consistency while defining the methodology of the IT experiments and to provide ease for reading, the following terms will be used according to the definitions given:

\section{PC}

The stimulus or the method applied in an experiment that triggers IT in the brain.

\section{Ischemic preconditioning (IPC)}

Method of PC by inducing either global or focal transient cerebral ischemia. When the PC stimulus is different than ischemia, $\mathrm{PC}$ will be named according to the nature of the trigger (e.g., hypoxic-PC, anesthetic-PC, chemical-PC). In the literature, sublethal or priming ischemia have been used as alternative terms to IPC. For subsequent ischemic insult given after PC, the term

Table 1 Main futures of cerebral ischemic tolerance

\begin{tabular}{ll}
\hline General & Preconditioning specific \\
\hline • Robust cerebroprotection & • Two phased: early and delayed \\
- The interval between preconditioning and ischemia determines & • Early tolerance starts in minutes, delayed tolerance not usually before \\
the fate & $24 \mathrm{~h}$ \\
- Ischemic tolerance is transient & - After early phase, but before delayed phase no tolerance is achieved \\
- Ischemic tolerance can be induced by a variety of stimuli & • Early phase is short-lasting, delayed phase longer, up to 1 week \\
- Transient ischemic attacks confer ischemic tolerance in humans & • Preconditioning preserves cortical/penumbral tissue in focal ischemia \\
\hline
\end{tabular}


test ischemia is often used [6,7], among others (final, lethal, reference, or full ischemia). We will prefer to name the subsequent ischemic event as final ischemia.

\section{IT}

Briefly, the protection from final ischemia provided by prior PC refers to as IT. Depending on the media used to study the phenomenon of IT, IT may refer to the cell, tissue, or organ's post-ischemic state wherein, due to previous $\mathrm{PC}$ exposure, the response to ischemia is different from one observed without previous PC. In this article therefore, PC and IT define two different (but related) entities and are not used interchangeably.

\section{Ischemia-tolerant phenotype (Figure 1)}

It is the consequence of both pre- and post-ischemic protective responses induced by PC [5]; in other words, it is the resulting phenotype from both $\mathrm{PC}$ and final ischemia.

\section{Latent cerebroprotective phenotype}

It determines the status of the cell, tissue, or organ exposed to $\mathrm{PC}$ that experiences changes triggered by $\mathrm{PC}$, and it occurs before the application of final ischemia [5]. Hence, the latent cerebroprotective phenotype differs from the ischemia-tolerant phenotype by the lack of exposure to final ischemia (Figure 1).

\section{Cerebroprotection or protection}

With the better understanding of the concept of neurovascular unit (i.e., the contribution of glial and vascular endothelial cells and their interactions with neurons in physiological and pathological conditions), researchers' attention shifted from neurons towards cerebrum. Hence, instead of "neuroprotection", we prefer to use "cerebroprotection", which covers not only neurons but all the cerebral cell populations experiencing IT. To interpret IT afforded on single cell type (hippocampal CA1 neurons in global ischemic models or type of cell slice used in vitro study), the protective effect provided by PC will be discussed as "protection".

\section{Two phases of IT}

Preconditioning induces two phases of IT with different temporal profiles and, to some extent, with different mechanisms of protection: early and delayed IT (Figure 1 ); the latter plays the major role in the brain. Early IT is a short-lasting protection induced within minutes of exposure to PC and wanes within hours. In this process, rapid changes in activity and posttranslational modifications of existing proteins are involved, whereas delayed IT requires gene induction and de novo protein synthesis, that represent a long-term response through genetic reprogramming [4]. If the final ischemia is induced during the unprotected window, which exists between early and late IT (usually $30 \mathrm{~min}-1$ hour after PC, lasting up to 24 hours), no tolerance occurs (Figure $1)$.

In the literature, early IT has been termed as the first window of protection [8], rapid IT [5], immediate IT [9], short-term protection [8], classical IT [10], or acute IT [4]. We will prefer to use early IT [10]. Alternative terms for delayed IT are: second window of protection (a term widely used in heart IT studies), classical IT [5], and late IT [11].

\section{Models for IT}

Study setups for investigating potential phenotypes induced by PC are exampled in Figure 2. A summary of the available rodent models of IT is included in the following link as Additional File 1.

\section{Global-Global}

Animal models of global cerebral ischemia are designed to mimic cardiac arrest in humans. Global-global IT models include different durations of transient global ischemia as PC and final insult.

\section{Four-vessel occlusion}

Rat forebrain ischemia experiments necessitate the occlusion of both posterior and anterior blood circulation of the brain. Four-vessel occlusion was originally described by Pulsinelli et al. [12] as a two-stage procedure wherein first both vertebral arteries are permanently closed and the following day, both carotid arteries are occluded. The model has been modified later by the same authors [13] and others [14]. In rats, delayed IT was provided by 3 [15] and 5 min [16] of four-vessel occlusion to 6 to $20 \mathrm{~min}$ of final global ischemia [15-17]. Appropriate durations of PC and the interval between $\mathrm{PC}$ and final ischemia in this scenario have been studied by monitoring postischemic Hsp72 protein expression as a marker of IT [18]. Neither 3, nor 8 min of IPC induced sufficient synthesis of Hsp72. Once PC was fixed to 4 to $5 \mathrm{~min}$, the minimum 2 days of interval was required between $\mathrm{PC}$ and final ischemia.

\section{Two-vessel occlusion and hypotension}

This model, originally described by Smith et al. [19] in the rat, includes bilateral carotid artery occlusion and systemic hypotension induced by withdrawal of arterial blood. Compared to four-vessel occlusion, it is less invasive and more reproducible, as the depth of ischemia depends on hypotension, rather than on surgical attenuation of collateral perfusion [20]. PC by 2 to 3 min of two-vessel occlusion induces delayed IT in rats to 5 to $10 \mathrm{~min}$ of final global ischemia [21-23]. Early IT was also achieved in this model [24]. 


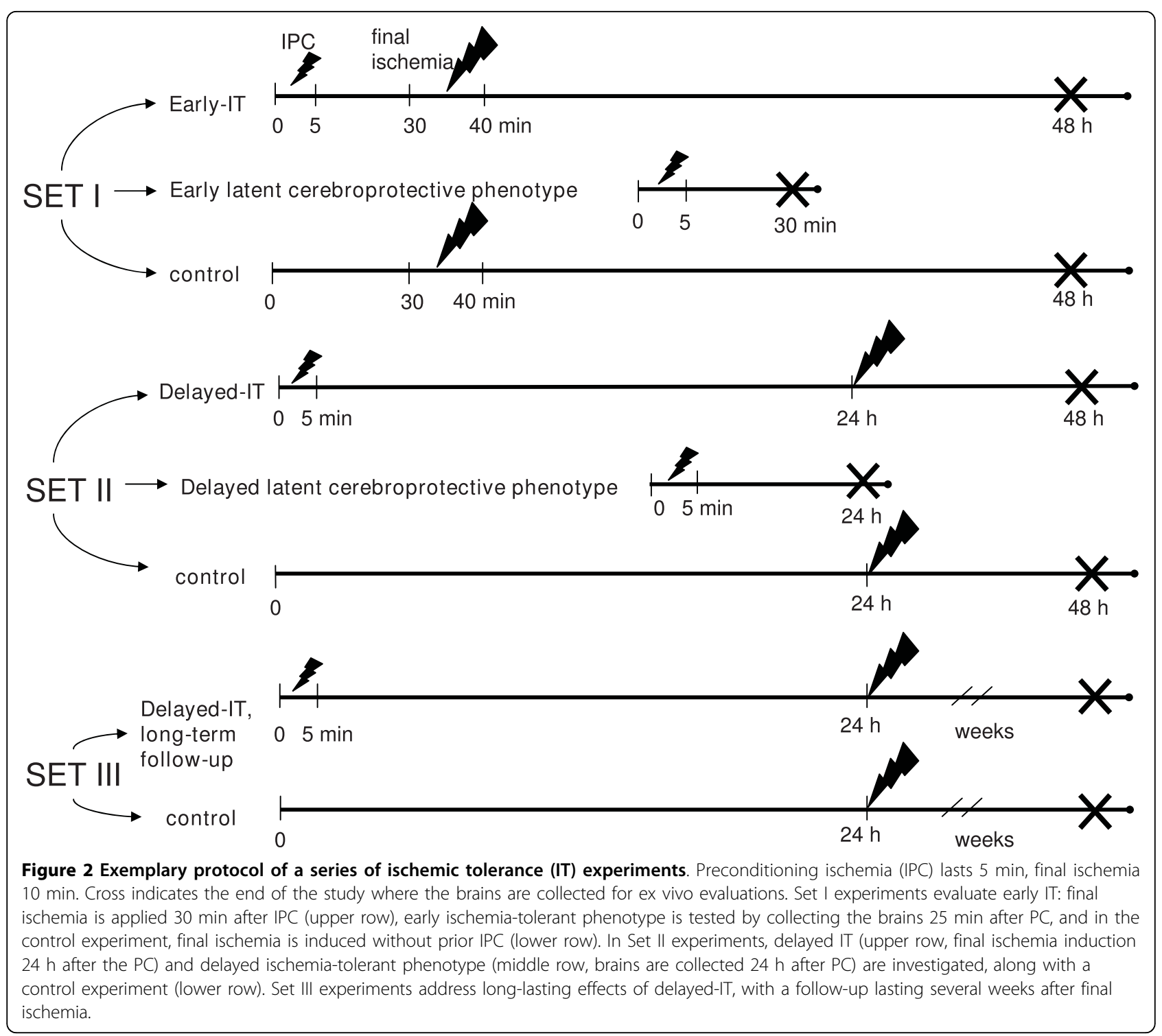

Two-vessel occlusion in gerbils

The gerbil mostly lacks a functioning circle of Willis [25], a short period of bilateral occlusion of carotid arteries (3-5 $\mathrm{min}$ ) therefore leads to severe damage in CA1 pyramidal neurons [26,27]. First introduced by Kitagawa et al. [3], PC by single 2-min bilateral carotid occlusion (or two times), 1 to 7 days before final ischemia in the gerbil brain has been a well-standardized method to study IT [28-30]. A disadvantage of the gerbil two-vessel occlusion model is that the severity of forebrain ischemia is highly influenced by the anatomical variations, which are not seldom [31]. Here, we should note that thresholds for severity (i.e., duration of the bilateral carotid occlusion), differentiating the outcome as either PC or final insult, are in a narrow scale. To overcome this issue and ensure a better control over the ischemia severity, Abe and colleagues [7] provided a useful modification of the model. By monitoring depolarizations, they largely eliminated the variability of the ischemia and IT. This approach later was introduced in a rat global-global IT model using four-vessel occlusion [32].

\section{Two-vessel occlusion in mice}

This method, borrowed from its equivalent in gerbils, may induce reproducible striatal injury in mice [33]. For a delayed IT paradigm, Wu et al. applied 6 min of twovessel occlusion as PC and 18 min of bilateral carotid artery occlusion as final ischemia in C57BL/6 mice [34]. As this strain is a common subject of transgenic technology, the model proved useful for investigating the molecular mechanisms of IT in gene-modified mice. In 
a such scenario, a much longer two-vessel occlusion period (20 $\mathrm{min})$ has induced delayed IT [35].

\section{Focal-Focal}

Transient focal-permanent focal

Transient occlusion of the middle cerebral artery (MCA) by intraluminal insertion of a nylon monofilament, which was originally described by Koizumi et al. [36] and modified by others [37], is the most common model to induce focal cerebral ischemia in rats [38-41] and also available in mice [42-45]. This method was introduced first time in a rat IT experiment, applying $10 \mathrm{~min}$ of transient MCA occlusion (tMCAO) as the PC stimulus and permanent MCAO as the final ischemia [46]. Authors evaluated IT phenomenon with several reperfusion periods between IPC and final ischemia and showed that ischemic lesions involving both cortex and basal ganglia could be reduced when final ischemia was applied 1, 2, and 7 days after PC, but not 2, 6, and 12 hours or 14 and 21 days after PC. This model was applied successfully by others to obtain delayed IT $[47,48]$. Repeated brief transient ischemia regimen was also proved as a preconditioning paradigm inducing early IT in mice subjected to permanent focal ischemia $[49,50]$.

\section{Transient focal-transient focal}

One [51,52] or 3 times of 10 min transient focal cerebral ischemia protects from subsequent $120 \mathrm{~min}$ of tMCAO in rats [53-55]. Shorter durations (2 and $3 \mathrm{~min}$ ) of tMCAO were severe enough to induce delayed IT, but did not provide early IT to transient ischemia [56,57]. Transient focal-focal IT paradigm induced IT also in mice and spontaneously hypertensive rats $[58,59]$. A recent mouse model of delayed-IT involves 2 periods of 5-min tMCAO as the PC method, against 90-min tMCAO applied in 3 days, but not in 2 or 4 days [6].

\section{Global-Focal}

Brief global ischemia can protect from both subsequent transient and permanent focal ischemia $[60,61]$.

\section{Focal-Global}

Brief unilateral occlusion of the MCA induced significant protection from global ischemia in both gerbils [62] and rats [63]. Interestingly, transient (20 min) occlusion of the distal MCA protected only ipsilateral parietal cortex of the rat from global ischemia (10 $\mathrm{min})$ [64].

\section{Cross-Tolerance}

Cross-tolerance is tolerance to ischemia provided by miscellaneous noxious stimuli, rather than ischemia. These differ greatly in nature, nevertheless, because of a common reason (most likely by inducing genetic reprogramming), all furnish IT. Examples of cross-tolerance in the scenario of transient focal cerebral ischemia are provided in Table 2.

\section{Hypoxia}

Exposure of neonatal rats to $8 \%$ oxygen for 3 hours provides cerebroprotection from a combined hypoxia/ischemia model [65] and also from both transient and permanent focal cerebral ischemia [66,67]. Varying hypoxia durations $(1,3$, or 6 hours) result in similar extent of protection, but when the interval between hypoxia and final ischemia exceeds 72 hours, IT abolishes [67].

\section{Hyperbaric oxygen}

Hyperbaric oxygen was found protective from subsequent global ischemia in gerbils [68] and from permanent focal ischemia in SV129 mice [69], whereas it did not induce IT to transient focal ischemia in these mice [69]. Rats were protected from transient ischemia by hyperbaric oxygen PC, but they were not protected from permanent ischemia [70]. Repeated hyperbaric oxygen application seems to induce IT to global ischemia in the rat brain for a shorter period than $72 \mathrm{~h}$ [71].

\section{Hyperthermia}

In rodent experiments, indirect brain temperature can be measured with a probe placed under the temporal muscle and can be maintained at a desired level by heaters allowing feedback adjustments. Chopp et al. first time observed the PC effect of hyperthermia in rats subjected to global ischemia [72]. Hyperthermia was protected as well neonatal rats from hypoxia/ischemia [73].

\section{Hypothermia}

The hypothermic-PC has been described in a rat model of focal transient ischemia [74] and later was studied systematically in order to define the optimal depth, duration, and the method of application (global versus focal hypothermia) [75]. The extent of protection was dependent on the depth and duration of the hypothermia, focal cooling being as effective as systemic cooling. Although the deeper the hypothermia, the bigger the IT response was, mild to moderate levels of hypothermia, which are safe in humans [76], were efficient as well. This may encourage clinicians to test hypothermia as a preconditioning strategy, for instance before vascular surgical interventions with high risk of ischemic events.

\section{Spreading depression}

Leão's spreading depression is a generalized and stereotyped response of the cerebral cortex to a variety of noxious stimuli and is characterized by a slowly moving, transient, and reversible depression of cortical electrical activity that spreads like ripples in a pond; these waves, 
Table 2 Amount of histological protection afforded by preconditioning in selected studies of focal cerebral ischemia

\begin{tabular}{|c|c|c|c|}
\hline & Protection* (\%) & Follow-up ${ }^{* *}$ & Ref. \\
\hline \multicolumn{4}{|l|}{ Focal-focal, in rats } \\
\hline 15 min MCAO - 72 h later PMCAO & 41 & $24 \mathrm{~h}$ & [47] \\
\hline 10 min $M C A O-72$ h later 60 min tMCAO & 44 & $7 d$ & [59] \\
\hline 3 min $\mathrm{tMCAO}-72 \mathrm{~h}$ later $60 \mathrm{~min} \mathrm{tMCAO}$ & 35 & $24 \mathrm{~h}$ & {$[57]$} \\
\hline \multicolumn{4}{|l|}{ Focal-focal, in mice } \\
\hline $3 \times 5$ min $\mathrm{tMCAO}-30$ min later $\mathrm{pMCAO}$ & 23 & $24 \mathrm{~h}$ & [50] \\
\hline $3 \times 5$ min tMCAO - 30 min later 60 min $\mathrm{tMCAO}$ & 32 & $24 \mathrm{~h}$ & [49] \\
\hline 15 min MCAO - 72 h later 45 min tMCAO & 70 & $24 \mathrm{~h}$ & [58] \\
\hline \multicolumn{4}{|l|}{ LPS } \\
\hline LPS $0.5 \mathrm{mg} / \mathrm{kg}$ - $72 \mathrm{~h}$ later $60 \mathrm{~min}$ tMCAO in rats & 35 & $24 \mathrm{~h}$ & [98] \\
\hline \multicolumn{4}{|l|}{ Hypoxia } \\
\hline $11 \%$ oxygen for $2 \mathrm{~h}-48 \mathrm{~h}$ later 90 min $\mathrm{tMCAO}$ in mice & $46-64$ & $24 \mathrm{~h}$ & [66] \\
\hline \multicolumn{4}{|l|}{ Anestesia } \\
\hline Isoflurane $1.4 \%$ for $3 \mathrm{~h}-0,12$, and $24 \mathrm{~h}$ later $\mathrm{PMCAO}$ in rats & $31-35$ & $4 d$ & [113] \\
\hline Halothane $1.2 \%$ for $3 \mathrm{~h}-24 \mathrm{~h}$ later pMCAO in rats & 35 & $4 d$ & [113] \\
\hline \multicolumn{4}{|l|}{ Spreading depression } \\
\hline $\mathrm{KCl}$ application -4 days later 120 min tMCAO in rats & 43 & $4 d$ & [191] \\
\hline \multicolumn{4}{|l|}{ Hyperbaric oxygen } \\
\hline $100 \%$ oxygen for 1 h, 5 days- 24 h later pMCAO in mice & 27 & $24 \mathrm{~h}$ & [69] \\
\hline
\end{tabular}

Ref, references; *Reduction in the ischemic damage due to preconditioning; **Time-point of the histopathological analysis after final ischemia

from the site of onset, spread usually to the whole cortex of the ipsilateral brain hemisphere with a speed of 2 to $5 \mathrm{~mm}$ per minute [77]. Topical application of high concentration of potassium chloride onto the cortex induces spreading depression that repetitively extends from the sites of increased extracellular potassium concentration with a frequency of approximately $7 / 100 \mathrm{~min}$ [78]. This method has been an effective PC trigger in both global [79] and focal ischemia models in rats [80-82]. IT induced by spreading depression seems to develop in a delayed manner (in 3-6 days) $[83,84]$ and was shown to persist up to 15 days [85].

\section{Remote IPC}

Limb ischemia by bilateral femoral artery occlusion protects rat from either global ischemia [86] or transient focal ischemia [87]. It can be applied as well repeatedly (5-10 min for 3 times, with 10 minutes intervals in between). This PC approach was successfully tested in humans to induce IT in the heart [88]. Mesenteric artery occlusion for 15 min was protective against bilateral carotid occlusion in mice [89].

\section{3-nitropropionic acid (3-NPA)}

This is the most extensively studied chemical PC agent, which inhibits oxidative phosphorylation. Intraperitoneal administration of 3-NPA, 72 hours before transient focal ischemia, is a well-established PC trigger for rats [90-93]. Regarding the efficacy of 3-NPA as a PC trigger, some contradictory results came from gerbil models of global ischemia [94-96], but these may be related to the doses used [97].

\section{Lipopolysaccharide (LPS)}

LPS is a cell-wall component of gram-negative bacteria. A small dose provides IT in the brain. This has been proven in a number of experiments including both transient $[98,99]$ and permanent $[100,101]$ focal ischemia models in rats, as well as in a mouse model of transient focal ischemia [102]. With higher doses no PC effect occurs [98].

\section{Anesthetic-PC}

Potential protective effects of anesthetics from an ischemic insult have been known for long time [2] and were well-studied in experimental stroke models as a cerebroprotective strategy (for reviews see [103-105]). Among anesthetics, isoflurane is the most commonly used volatile anesthetic in IT experiments. Different concentrations (0.5-4\%) and varying durations (15 min-3 hours) of isoflurane inhalation have been efficient to induce both early $[106,107]$ and delayed IT in vivo $[108,109]$ and in vitro models $[110,111]$. Among other anesthetics, xenon [112], halothane [113], and sevoflurane [114] may also induce IT in animal models. Anestetic-PC has been proven a promising PC method for heart in humans [115].

\section{Pharmacological PC}

Several clinically available drugs, including estrogen [116], erythromycin $[117,118]$, and erythropoietin 
$[119,120]$, are capable of inducing IT in animal models. Acetylsalicylic acid [121] and kanamycin [122] were effective as PC agents in vitro.

\section{Other models for IT}

Repeated electroacupuncture [123,124], electrical stimulation of cerebellar fastigial nucleus [125], and dietary restriction [126] protected rats from subsequent transient focal ischemia. In global ischemia rat models, repetitive transcranial magnetic stimulation [127], electroconvulsive shock [128], kainite-induced epileptic seizures [129], and sleep deprivation [130] all have served as PC stimuli.

\section{In vitro models}

Neuronal cell culture systems provide an ideal microenvironment to study PC, because they lack a vascular compartment and the environment is easily controlled for confounding factors (e.g., see the fascinating work by Gonzalez-Zulueta et al. [131]). In vitro modeling for ischemia consists of oxygen and glucose deprivation (OGD) in the culture medium, and perhaps the most widely used method is the one described by Goldberg and Choi [132,133]. This model includes the transfer of neocortical cell cultures for several hours to an anaerobic chamber containing a gas mixture of $5 \% \mathrm{CO} 2,10 \%$ $\mathrm{H} 2$, and $85 \% \mathrm{~N} 2$ (oxygen deprivation), followed by application of a deoxygenated glucose-free medium (glucose deprivation). Organotypic hippocampal slice cultures offer an attractive alternative method, because many aspects of in vivo ischemia, such as delayed death of CA1 neurons and selective vulnerability in response to OGD, can be addressed [134]. Hassen et al. has introduced a new model of IT by isolating hippocampal slices from young rats, to abolish age-dependent resistance to ischemic injury [135]. Also mixed neocortical cultures are available to study IT in vitro [136].

\section{Methods for detecting IT}

In most of the IT studies, the ischemia-tolerant phenotype is addressed with assessments performed after the final ischemia; however, to expose the molecular substrates of latent cerebroprotective phenotype, the tissues should be collected after PC (Figure 2). Studies, which used the latter approach, have been recently reviewed [137]. To increase the relevance to the human condition, IT models should include both histological and functional evaluations. However, these imply more challenges for IT researchers [138], because not always a correlation between these two outcome parameters is present [30].

\section{Histological techniques}

Determining the extent of injury after focal ischemia is relatively simpler than after global ischemia. For this purpose, traditional histological staining techniques, such as hematoxylin-eosine and $2 \%$ solution of 2,3,5-triphenyltetrazolium chloride, are often used. Digital camera-based image analysis systems enable lesion area and volume calculations. Ischemic lesion volume is calculated preferably with the correction of edema effect $[38,39,139,140]$. In IT experiments, reduction in lesion volume due to PC (lesion size in the näive brain lesion size in the preconditioned brain) can be calculated as a percent ratio to the lesion size in the näive brain (Table 2). In global ischemia models, ischemic damage is assessed in hippocampal sections stained with toluidine blue [141], cresyl violet [34,94], or thionin [142] by counting CA1 neurons, which are highly susceptible to global ischemia and easy to quantify due to their laminar distribution and large size [138]. Protection due to $\mathrm{PC}$ can be reported as the percentage of preserved healthy hippocampal CA1 neurons or number of viable CA1 neurons [7,30,129]. In vitro models of IT use cellular injury assessments, such as lactate dehydrogenase assay $[111,143]$.

\section{Functional assessment}

Gross measures of sensorimotor abilities are available for rodents $[37,144]$, and were introduced in IT experiments $[46,47,97,107]$. However, in these species, gross sensorimotor deficits tend to recover rapidly. That is, more complex tests are needed, especially if outcome is assessed in longterm. A number of somatosensory tests (e.g. limb placing, beam walking, grid walking, rotarod) are available to apply in focal ischemia rat models [145]. In global ischemia models, tests of learning ability, and working and reference memory are particularly useful $[138,146]$.

\section{Lesion evaluation by magnetic resonance imaging (MRI)}

MRI technology allows for temporal and spatial monitoring of ischemic lesion and enables to conduct longitudinal studies [147-151]. Besides requiring anesthesia, MRI is risk-free for experimental animals. First MRIbased lesion evaluation in an experimental IT study was reported by Mullins et al. [152]. In a delayed IT model (focal-focal ischemia), rats were imaged 24 and 72 hours after final ischemia. Interestingly, lesion reduction due to PC was greater at 72 hours (70\%) compared to that at 24 hours (53\%). Authors concluded that 24 hours post-ischemia, which is a common time-point for lesion evaluation in experimental stroke studies [153-155], may not be the best time-point for experimental IT studies. Furuya et al., imaged rats serially (at 6 and 24 hours and 4, 7, and 14 days), following a delayed IT paradigm (LPC-PC-focal ischemia) [156]. They evaluated whether decreased lesion size due to PC would increase in long-term. No delayed lesion progression was found. 


\section{Means for depicting the mechanisms of IT}

Immmunohistochemistry is widely applied in IT research and serves to evaluate tissue alterations by means of antigen-antibody interactions. In situ hybridization and Western blotting techniques are applied to examine the effect of PC on the investigated protein's mRNA expression and abundance [141]. DNA microarray technology, which allows quantification and differential expression of thousands of genes simultaneously, has been used to investigate global changes occurring between ischemia-tolerant and näive brains (see below "genomic reprogramming"). Real-time PCR can be used for confirmation of the selected genes, which found upregulated by microarray analysis [157]; proteomics may provide supplemental insights [158]. Alterations in neurotransmitter receptor density can be evaluated by quantitative in vitro receptor autoradiography $[159,160]$. Autoradiographical methods may show changes in the global protein status $[29,161]$.

Showing attenuation or abolishment of IT by pharmacological inhibition of a molecule before or after PC stimulus proves a robust approach. With this approach, necessary or mandatory components of IT can be explored [162,163]. Complementary information may come from genetically modified animals by proving abolishment of IT in mutants lacking a functional molecule or protein and showing reestablishment of IT in rescue experiments [164]. Maintenance of IT, despite pharmacological inhibition of a molecule of interest or despite the lack of this molecule in the mutant mouse, may rule out the hypothetic causative role for the investigated molecule in the acquisition of IT $[35,84,163]$. However, it should be noted that, the main effectors of IT can be model- or trigger-specific that, for instance, a specific molecule proven mandatory for hypoxia-induced IT in the rat brain [165] may not necessarily be required in OGD-induced IT in vitro [166].

\section{Mechanisms of IT}

IT is achieved by the attenuation of broad categories of injury-inducing mechanisms, including excitotoxicity, ion and $\mathrm{pH}$ imbalance, oxidative and nitrosative stress, metabolic dysfunction, inflammation, and apoptotic cell death. Additionally, innate survival mechanisms and enhanced endogenous repair mechanisms are involved [5]. Preservation of energy metabolism and mitochondrial functions during the ischemic event is improved $[167,168]$. Our knowledge on the underlying mechanisms of cerebral IT is yet patchy. Additionally, different mechanisms may dominate different models. Here, we will review only the major molecular aspects contributing to delayed cerebral IT. The mechanisms of early IT will be discussed separately at the end of this section. Readers seeking for more comprehensive information should consult the recent excellent review of Obrenovitch [169] as well as its antecedents $[9,133,167]$.

\section{Hypoxia-inducible factor-1 (HIF-1)}

Among several transcription factors sensitive to regulation by hypoxia/ischemia, HIF isoforms have gained the most experimental support [5]. HIF-1 proteins are increased in the brain in the setting of hypoxia resistance [170] and hypoxic PC [67]. Pharmacological activators of HIF-1 (deferoxamine or cobalt chloride) promote $\mathrm{PC}$ in hypoxia/ischemia model in neonatal rats [170]. Over the past decade, the signalling pathways involved in HIF-1 activation have been deciphered in detail [171]. Briefly, hypoxia stabilizes alfa subunit of HIF-1, which enters the nucleus in a dimerized form and results in the induction of HIF target genes. Several HIF target genes contribute protection from ischemia $[67,172,173]$, and their products involve in wide range of adaptive and pro-survival events, including cellular metabolism, proliferation, vascularization, iron homeostasis, and glucose metabolism $[5,133]$.

\section{Protein kinase C (PKC)}

The role of protein kinase $C$ in mediating stroke injury has been reviewed recently [174]. There are 10 isozymes in the PKC family. Previously, PKC was thought not to have a role in IT phenomenon, because blockage of PKC did not prevent IT [175], and PKC activation did not induce IT [176]. However, accumulating data suggest opposite roles for different PKC isozymes in the brain: $\gamma$ PKC contributes in ischemic cell death in organotypic hippocampal cell cultures, and NMDA triggered IT models require $\varepsilon$ PKC translocation [177]. Even though non-selective activation of PKC does not induce IT, specific $\varepsilon$ PKC activation leads to IT [143,177]. It seems that adenosine-mediated activation of $\varepsilon P K C$ and subsequent signal transduction pathways through MAPK-K, ERK [178], and cyclooxygenase-2 induction are involved in IT [143].

\section{Anti-excitotoxic mechanisms, NMDA, and calcium}

Exogenous application of NMDA or glutamate alone suffice to induce ischemia resistance in cell cultures, and NMDA receptor blockade during preconditioning eliminates IT both in vitro [179] and in vivo [180,181]. Specific AMPA or kainate receptor blockade do not eliminate or only partially attenuates IT $[131,180]$. Contradictory findings exist, however [136,182]. In gerbils, IPC increased inhibitory $\gamma$-amino butyric acid A $\left(\mathrm{GABA}_{\mathrm{A}}\right)$ receptor binding in hippocampus, whereas final ischemia did not [160]. Moreover, microdialysis experiments revealed a temporary increase in GABA release in preconditioned rat hippocampus early after final ischemia, with a decrease in glutamate 
concentration [21]. Thus, anti-excitotoxic mechanism induced in ischemia-tolerant state in global ischemia models involve a shift between inhibitory and excitatory hippocampal neurotransmission. In vitro, $\mathrm{GABA}_{\mathrm{B}}$ activation operates as a PC trigger [21], but not $\mathrm{GABA}_{\mathrm{A}}$ activation [21,183]. Regarding the role of $\mathrm{Ca}^{2+}$ in IT, it seems not always mandatory [184], but chelation of $\mathrm{Ca}^{2}$ ${ }^{+}$before and during both OGD- and NMDA-PC prevents IT in vitro [177].

\section{Adenosine and ATP-sensitive $\mathrm{K}^{+}\left(\mathrm{K}_{\mathrm{ATP}}\right)$ channels}

Adenosine, an ischemia-induced degradation product of ATP, activates $A_{1}$ receptors, which leads to a cascade of signaling events including $\mathrm{K}_{\mathrm{ATP}}$ channels. This cascade results in increased resistance to subsequent ischemic damage [185]. The general role of $\mathrm{K}_{\mathrm{ATP}}$ channels, which are named for the inhibitory effect of ATP reducing channel opening probability, is to set membrane potential according to its metabolic state by sensing intracellular nucleotide concentrations [186]. Plasma membrane $\mathrm{K}_{\text {ATP }}$ channels are found widely throughout the brain [186]. The mandatory role of $\mathrm{K}_{\mathrm{ATP}}$ channels for acquisition of IT was demonstrated in a rat delayed IT model (global-global) [187] and in vitro [188]. Interestingly, early IT is also blocked by pharmacological inhibition of $\mathrm{K}_{\mathrm{ATP}}$ channels in vitro [176]. Opening of $K_{\text {ATP }}$ channels is thought to relate to adenosine A1 receptor activation. Both specific and nonspecific adenosine A1 receptor antagonists attenuate or cancel the IT phenomenon $[187,189,190]$. However, SUR1-containing $\mathrm{K}_{\text {ATP }}$ channels seem not to be involved in IPC [35] and in spreading depression-PC model in rats and inhibition of $\mathrm{K}_{\mathrm{ATP}}$ channels did not block IT [191]. Some authors emphasize a more pronounced role for mitochondrial $\mathrm{K}_{\mathrm{ATP}}$ channel in IT $[169,190]$.

\section{Nitric oxide (NO)}

$\mathrm{NO}$ is one of the most extensively studied molecules in IT experiments (for reviews see [192,193]). Data suggest that generation of NO is crucial for the induction of IT, as a dependence on endothelial NO synthase (eNOS), but not on the neuronal NOS (nNOS) in newborn rats subjected to hypoxic-PC [165]. Whereas, nNOS was required to induce tolerance in vitro [166]. OGD tolerance in cortical cell cultures occurred via the activation of the Ras/extracellular signal-regulated kinase cascade by NO [131]. Atochin's early IT model proved an indispensable role for both eNOS and nNOS [50]. Puisieux et al. used a delayed IT (focal-focal) model in adult rats and showed no effect of NOS blockade on IT, but when the PC stimulus was LPS, IT was abolished by NOS inhibition [194]. Inducible NOS (iNOS) lacking mice experience no IT [164] and iNOS inhibition may nullify delayed IT to permanent focal ischemia, that otherwise follows isoflurane- or halotane-PC [113].

\section{Anti-inflammatory mechanisms}

Interleukin-1 (IL-1) and tumor necrosis factor- $\alpha$ (TNF$\alpha)$ are implicated in IT induction: both cytokines are found increased in ischemic-tolerant state, both act as PC trigger when administered systemically, and their inhibition or lack significantly attenuate or block IT [195-198]. Pradillo et. al. explored the involvement of the TNF- $\alpha$ /nuclear factor $-\kappa \mathrm{B}(\mathrm{NF}-\kappa \mathrm{B})$ signal transduction pathway in IT [48]. This pathway includes at least 131 interactors [199]. Activation of NF- $\kappa \mathrm{B}$ is involved in IT in several models [200,201], likely via the induction of neuroprotective gene products, such as manganese superoxide dismutase and Bcl-2 [9]. Preconditioning with ligands of toll-like receptors 4 and 9 may alter innate inflammatory responses to ischemia by causing an initial activation of inflammatory mediators followed by a burst of inflammation inhibitors [202].

\section{Anti-apoptotic mechanisms}

PC blocks enhanced phosphorylation occurring after ischemia [9]. On the other hand, phosphorylation of transcriptional factors can induce long-term changes by regulating the expression of genes. IT is also characterized by reduced apoptosis $[5,142]$. Phosphaphatidylinositol 3-kinase/Akt pathway seems to act in two ways: 1) in relation to anti-apoptotic mechanisms and 2) by activating NFkB. In vitro, p21 Ras is required and sufficient to induce IT and Ras/Erk pathway is activated through NMDA receptor and NO production [131]. However, increasing evidences support the existence of a link between Akt activation and anti-apoptosis in IT $[157,203-205]$, perhaps more persistently in penumbral regions in focal IT models [206]. Anti-apoptotic mechanisms induced by PC are several: induction of Bcl-2, reductions in caspase- 3 synthesis and p-53 activation, and reductions in mitochondrial cytochrome $\mathrm{c}$ $[9,185]$.

\section{Genomic reprogramming}

With the contribution of DNA microarray analysis method to IT research, we gained a better understanding of the preconditioned brain on the genetic level. In 2003, Stenzel-Poore and colleagues published a study, a cornerstone in the field, which introduced the concept of "genomic reprogramming" defining the altered transcriptional response of the ischemia-tolerant brain [207]. Followed by others [208,209], profiled the genetics of IT induced by IPC in rats were profiled. In the setting of IT, overall transcriptional response to injury was found altered as downregulation, which was strikingly different from that in the naïve brain's postischemic transcriptome. Suppression of gene expression in the ischemiatolerant state was not simply the lack of response to injurious insult, but rather a reprogramming of the 
genetic response to ischemia [210]. Most of the genes suppressed are involved in the pathways that regulate metabolism, molecular transport, or cell-cycle control. Genomic transcriptional profile shows a substantial difference also between latent cerebroprotective and ischemia-tolerant states. None but one of the differentially regulated genes compared to healthy hemisphere are in common [208]; however, in both states, overall response is downregulation of genes involved in metabolism and transport/synaptic transmission. Using GeneChip analysis, Dhodda et al. evaluated temporal changes in gene expression after IPC in spontaneously hypertensive rats [158]. At the time-points studied $(3,6,12,24$, and $72 \mathrm{~h}$ after PC), overall 40 transcripts were found up-regulated, among which 30 transcripts were overexpressed at all time-points, and the six HSP70 transcripts showed the highest increase. Other major families of transcripts, which were upregulated during $\mathrm{PC}$, were those that control signal transduction, transcription, ionic homeostasis, and plasticity. Moreover, transcripts that showed upregulation after ischemia in näive brains were not found upregulated in ischemia-tolerant brains [158].

Gene expression response to hypoxic-PC was also studied [173]. As early as 1 hour after hypoxia, but at a greater extent at 6 hours, expression of many genes, which are regulated by HIF-1, were increased. Compared to näive ischemic brains, in the ischemia-tolerant brains preconditioned with hypoxia, several genes were differentially upregulated. Genes with decreased expression in näive ischemic brains were no longer or only to a small degree underexpressed in ischemia-tolerant brains.

Genetic response to hyperbaric oxygen-PC was studied in the rat, in the latent cerebroprotective state (at 6,12 , 24 after PC) [71]. Most of the differential regulations, including overexpression of genes and proteins related to neurotrophin and inflammatory-immune system, occurred around 12 and 24 hours. Genetic reprogramming was described as well for IT induced by erythromycin [118].

\section{Mechanisms of early IT}

In vivo models demonstrating early IT in the brain are limited: global-global model in the rat [24], and focalfocal model both in the rat [211], and mouse [49,50], and anesthetic-PC against focal permanent ischemia in the rat [113].

The molecular mediators of early IT are little known. Changes in membrane channel activity and posttranslational modifications of existing proteins are among the few, which are well-described. Roles for adenosine receptor in vivo [211] and for $\mathrm{K}_{\mathrm{ATP}}$ channel in vitro were also explored [176]. Several immediate-early genes (c-fos, c-jun), growth factors (brain-derived neurotrophic factor, nerve growth factor), and heat shock protein 70 were overexpressed during early latent ischemia-tolerant state [212]. According to Kariko et al. [213], during early tolerance, production of proinflammatory cytokines are suppressed, whereas in delayed tolerance, production of the very same cytokines are induced.

\section{Open Issues and Challenging Features of IT}

Several specific questions arise by an overview of past IT experiments. The nature of the $\mathrm{PC}$ stimulus and the duration of the interval between $\mathrm{PC}$ and final ischemia are among the main parameters that may affect the results. The strain and gender of the experimental animal are additional sources of variability, as we are familiar from stroke experiments. Therefore, findings of an experimental IT study should be interpreted considering the following issues.

\section{Trigger-dependent differences}

Experimental data amounted for the last 20 years clearly demonstrated that IT can be afforded in animals by miscellaneous PC triggers. Thus, one can both easily and reasonably make the following assumption: diverse PC are sharing a common or overlapping pathway. As discussed above, a number of effector mechanisms confer ischemia-tolerant phenotype, and recently, genetic reprogramming was proposed as the underlying common process set into motion by these mechanisms $[207,208]$. Below, we will have a closer look to studies comparing the mechanistic or molecular features of IT triggered by different PC stimuli.

IPC versus LPS-PC was compared in a transient ischemia rat model and found inducing similar degree of protection (35\% reduction in infarct volume) [194]. An interesting finding was that NO synthase inhibition abolished the protective effect of LPS, but not of IPC. IPC induced the expression of heat shock protein 70 in the cerebral cortex, but LPS did not. Recently, ischemiatolerant phenotypes induced by two well-known preconditioning stimuli -LPS and transient focal ischemiahave been evaluated from the genetic aspect [209]. Authors disclosed that a substantial subset of regulated genes were unique to each PC stimulus. In case of IPC, mainly metabolism and channel/transport-related genes were suppressed; whereas, LPS-PC induced expression of pro-inflammatory molecules and suppressed those genes related to deleterious inflammatory reactions. However, suppression of Toll-like receptor-mediated inflammation is a common mechanism triggered by both PC triggers [213]. Another comparative study of different PC stimuli (IPC and chemical PC with 3-NPA) addressed cytokine mRNA expression after final ischemia [214]. Both PC strategies exerted very similar effects on proinflammatory and cytotoxic cytokine expressions. 
Later, same authors studied the expression of nerve growth factor separately with IPC and 3-NPA-PC paradigms [215]. Neither trigger showed any effect on nerve growth factor expression, which in another study was found increased by PC with brief global ischemia in both early and delayed IT [212].

\section{Intermodel differences}

In focal-global IT paradigm, PC may confer IT in neurons outside the primary area subjected to IPC that is in proximity, but not in the further regions such as contralateral hippocampus [62]. Similar IT paradigm in rats resulted in bilateral protection of hippocampi, however [63]. A functional direct pathway from the entorhinal cortex to both hippocampi was suggested to reflect the changes afforded by IPC to both hemispheres [63]. In the global-global IT paradigm, c-fos expression during the tolerant state was found specific to the cell type [216], which may explain selectivity of IT induction to certain brain areas.

Prass et al. studied the confounding effects of strain and reperfusion on the IT phenomenon [69]. Hyperbaric oxygen was applied as PC stimulus to two common background strains for knockout mice, SV129 and C57BL/6. Final ischemia was either permanent or transient focal ischemia. In SV129 mice, PC induced tolerance to permanent ischemia but not to transient ischemia. In C57BL/6 mice, IT did not occur at all. Consequently, questions to answer with further study are: 1 . For what reasons the very same trigger induced IT in a strain but not in another, and 2) Can reperfusion nullify the protection afforded by PC?

\section{Gender}

Female rats sustain smaller infarcts after MCAO than males [217] and estrogen is neuroprotective in ovariectomized females and in males subjected to ischemic stroke [218]. Data from heart IT experiments show a clear gender-dependency of the IT phenomenon $[219,220]$, this issue seems valid also in cerebral IT. Estrogen provided IT in a model of hippocampal organotypic slice culture, which was generated from neonatal female rats [116], and isoflurane induced IT only in male mice and increased the infarction in young female mice [221].

\section{Age}

IT phenomenon is preserved in aged animals [222], but may not be as effective as it is in young animals. This aspect was tested with a global-global IT paradigm applied in 4- and 24-month-old rats [223]. The degree of protection due to $\mathrm{PC}$ was significantly diminished in aged rats compared to young rats. A retrospective clinical study indicated that IT may not be occurring in the elderly, aged around 75 [224].

\section{Repeated PC}

Cumulative injurious effect of repeated cerebral ischemia is a well-known phenomenon. For example, three periods of 5-min forebrain ischemia, induced at 1-hour intervals, result in more extensive brain injury than one single episode of 15-min ischemia in gerbils [225]. However, if PC insults are applied repeatedly, a larger IT response may be gained. This was tested in a mice model of early IT, in which animals underwent either single or 3 episodes of 5 -min focal cerebral ischemia, 30 min before permanent ischemia [49]. Only repeated insults conferred IT, the single brief ischemia was insufficient to induce IT. Similarly, a single episode of $2 \mathrm{~min}$ OGD is under the threshold to act as a PC stimulus, but four times repeated 2 min of OGD show a cumulative effect and protects from subsequent injurious insult [226]. Hyperbaric oxygen-PC, when applied singly or repeatedly, provide similar degree of protection from transient focal ischemia (63\% vs $73 \%$ lesion reduction) [227], perhaps this is the maximum affordable protection by hyperbaric oxygen. In a clinical study however, anesthetic-PC with a single application induced no IT in the heart, whereas repeated application did [115]. In the pig heart, PC by repetitive ischemic insults was shown to induce a different set of genetic regulations from those induced with PC with single ischemic episode [228]. A corresponding study in cerebral IT is needed.

\section{"Sublethality" of PC}

Although PC is defined as a sublethal stimulus, which per se causes no injury, several studies used relatively severe focal ischemia as the PC trigger and were able to induce IT, despite the injurious nature of the PC itself $[63,64,190]$. As pointed out by Sommer [137], with extended follow-up after the PC insult, some injury or structural changes can be detected. Therefore, it is suggested that PC is postponing these changes [137]. If that holds true, in the long-term, näive ischemic brains and IT experienced brains may have similar outcomes. This issue is discussed next.

\section{IT and long-term effects}

Early IT is a short-lasting phenomenon, its protection vanishes around 7 days [24]. In delayed IT models, protection lasts longer and tends to decline after 30-60 days. Ohno et al. applied a global-global IT model to rats [229] and showed that improvement in learning and memory due to IPC was preserved up to 3 weeks. Protective effects of spreading depression-PC and LPS-PC sustained up to 14 days $[84,156]$. Ma et al. found a sustained improvement in neurological scores up to 30 days in xenon-preconditioned neonatal mice subjected to global ischemia [112], a similar finding was reported with a focal-focal IT model in rats [51]. In global-global 
IT models, histological protection is longer preserved in rats (up to 90 days) than in gerbils (up to 60 days) $[30,32,222,230]$. Optimizing time interval between PC and final ischemia, together with the optimization of the PC stimulus (single or repetitive application) and the severity of final ischemic insult, may result in long-term preservation of protection achieved by PC [32], on which increased neurogenesis after PC [231] may have a potential role.

\section{Clinical Aspects}

To date, a body of evidence, which supports the hypothesis that TIAs may confer IT in humans, exists. In a retrospective study, preceding TIA was found to be associated with less-severe stroke on admission and improved outcome on follow-up, compared to stroke patients without preceding TIA [232]. Another retrospective case-control study, found no evidence of PC by TIA in baseline neurological scores, but favorable outcome was associated with the presence of TIA [233]. This study presented "potentially preconditioning" TIA characteristics as: 0-7 day interval between TIA and stroke, 2 or 3 times repeated TIA, and TIA with $<20$ min duration. Moncayo et al. reported a cohort of 65 patients with acute anterior circulation stroke, among whom those with previous TIAs (lasting less than 20 minutes), had a more favorable outcome than those without [234]. Apparently, duration of TIA should be taken into account while evaluating whether IT exists in humans or not [235]. An MRI study provided the tissue evidence for TIA-induced tolerance to ischemic stroke [236]. Ischemic lesions tended to be smaller on the baseline images and final infarct volumes were smaller in stroke patients with prior TIA than in those without.

Although these findings strongly suggest TIA as the clinical correlate of IPC, other explanations for milder strokes after preceding TIA must be considered. In these patients, a carotid disease with slowly progressing stenosis, which improves collateral circulation may predominate [237]. Another point is that, patients with cardioembolic stoke have lower incidence of TIA than those with atherosclerotic vascular disease, and probably because of larger-sized emboli they sustain larger infarcts and poorer outcome [238].

Several clinical conditions may benefit from strategies using principles of ischemic tolerance, as discussed elegantly by Dirnagl et al. in a recent review article on cerebral IT [239]. Mediators of IT could be used as biochemical markers of IT in stroke patients. Castillo et al. tested this hypothesis by evaluating blood levels of TNF- $\alpha$ and IL- 6 in acute stroke patients with or without prior ipsilateral TIA [240]. Better outcome was found in patients with TIA, who showed high plasma concentrations of TNF- $\alpha$ and low concentrations of IL- 6 . Hence, authors proposed the index of TNF- $\alpha / \mathrm{IL}-6$ as a marker of IT phenomenon in humans.

\section{Conclusions}

Experimental IT paradigms investigate the endogenous pathways by which the brain might protect itself from ischemia when geared with an appropriate stimulus. Attempts to elucidate the mechanisms underlying cerebral IT are increasing exponentially, but diversity of models, including PC stimuli, hardens interpretation of the data. In addition, narrow safety margin of $\mathrm{PC}$ may prove a limiting factor of the therapeutic utility of $\mathrm{PC}$ in clinics. On the other hand, accumulating clinical data suggest that IT might be a clinically relevant phenomenon. Several approaches, including ICP [241], remotePC by limb ischemia [88], pharmacological-PC with nitroglycerine [242], and anesthetic-PC [115], are tested in clinical trials to protect the heart from cardiovascular interventions with high risk of cardiac ischemic event. Results are promising and give hope that clinical trials of PC to protect brain in situations with a high risk of ischemia can be designed, once PC is proven safe.

\section{Additional file 1: Models for ischemic tolerance in rodents. \\ Click here for file \\ [http://www.biomedcentral.com/content/supplementary/2040-7378-2-2- S1.XLS ]}

\begin{abstract}
Abbreviations
3-NPA: 3-nitropropionic acid; GABA: $\gamma$-amino butyric acid; HIF-1: hypoxiainducible factor-1; IL-1: interleukin-1; IT: ischemic tolerance; IPC: ischemic

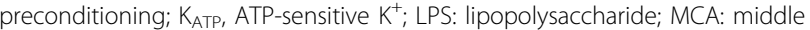
cerebral artery; MCAO: middle cerebral artery occlusion; MRI: magnetic resonance imaging; NO: nitric oxide; nNOS: neuronal NO synthase; iNOS: inducible NOS; eNOS: endothelial NOS; NF- $\mathrm{B}$ : nuclear factor ${ }_{k} \mathrm{~B}$; OGD: oxygen-glucose deprivation; PC: preconditioning; PKC: protein kinase C; TIA: transient ischemic attack; TNF- $\alpha$ : tumor necrosis factor- $\alpha$; tMCA: transient $\mathrm{MCAO}$
\end{abstract}

\section{Acknowledgements}

This work was supported in part by the Helsinki University Central Hospital and the Finnish Academy of Sciences.

\section{Authors' contributions}

Both $A D$ and $T T$ made the conception and design of the manuscript and analysis and interpretation of the data, drafted and revised the manuscript, and have given approval of its final version.

\section{Competing interests}

The authors declare that they have no competing interests.

Received: 6 July 2009

Accepted: 21 January 2010 Published: 21 January 2010

\section{References}

1. Dahl NA, Balfour WM: Prolonged anoxic survival due to anoxia preexposure: Brain ATP, lactate, and pyruvate. Am J Physiol 1964, 207:452-456.

2. Wells BA, Keats AS, Cooley DA: Increased tolerance to cerebral ischemia produced by general anesthesia during temporary carotid occlusion. Surgery 1963, 54:216-223. 
3. Kitagawa K, Matsumoto M, Tagaya M, Hata R, Ueda H, Niinobe M, Handa N, Fukunaga R, Kimura K, Mikoshiba K, Kamada T: 'Ischemic tolerance' phenomenon found in the brain. Brain Res 1990, 528:21-24.

4. Koerner IP, Alkayed NJ: Ischemic preconditioning. Acute stroke, bench to bedside New York: Informa HelthcareBhardwaj A, Alkayed NJ, Kirsch JR, Traystman RJ 2006, 345-353.

5. Gidday JM: Cerebral preconditioning and ischaemic tolerance. Nat Rev Neurosci 2006, 7:437-448.

6. Zhang J, Yang ZJ, Klaus JA, Koehler RC, Huang J: Delayed tolerance with repetitive transient focal ischemic preconditioning in the mouse. Stroke 2008, 39:967-974.

7. Abe H, Nowak TS Jr: Induced hippocampal neuron protection in an optimized gerbil ischemia model: insult thresholds for tolerance induction and altered gene expression defined by ischemic depolarization. J Cereb Blood Flow Metab 2004, 24:84-97.

8. Perez-Pinzon MA, Basit A, Dave KR, Busto R, Veauvy C, Saul I, Ginsberg MD, Sick TJ: Effect of the first window of ischemic preconditioning on mitochondrial dysfunction following global cerebral ischemia. Mitochondrion 2002, 2:181-189.

9. Kirino T: Ischemic tolerance. J Cereb Blood Flow Metab 2002, 22:1283-1296.

10. Trendelenburg G, Dirnagl U: Neuroprotective role of astrocytes in cerebral ischemia: focus on ischemic preconditioning. Glia 2005, 50:307-320.

11. Perez-Pinzon MA: Neuroprotective effects of ischemic preconditioning in brain mitochondria following cerebral ischemia. J Bioenerg Biomembr 2004, 36:323-327.

12. Pulsinelli WA, Brierley JB: A new model of bilateral hemispheric ischemia in the unanesthetized rat. Stroke 1979, 10:267-272.

13. Pulsinelli WA, Duffy TE: Regional energy balance in rat brain after transient forebrain ischemia. J Neurochem 1983, 40:1500-1503.

14. Schmidt-Kastner R, Paschen W, Ophoff BG, Hossmann KA: A modified fourvessel occlusion model for inducing incomplete forebrain ischemia in rats. Stroke 1989, 20:938-946

15. Choi JS, Kim HY, Cha JH, Lee MY: Ischemic preconditioning-induced activation of ERK1/2 in the rat hippocampus. Neurosci Lett 2006, 409:187-191.

16. Danielisova $V$, Gottlieb $M$, Nemethova $M$, Burda J: The effect of preconditioning on the iron deposition after transient forebrain ischemia in rat brain. Arch Ital Biol 2004, 142:87-94.

17. Zhang QG, Han D, Xu J, Lv Q, Wang R, Yin XH, Xu TL, Zhang GY: Ischemic preconditioning negatively regulates plenty of $\mathrm{SH} 3$ s-mixed lineage kinase 3-Rac1 complex and c-Jun $\mathrm{N}$-terminal kinase 3 signaling via activation of Akt. Neuroscience 2006, 143:431-444.

18. Burda J, Hrehorovska M, Bonilla LG, Danielisova V, Cizkova D, Burda R, Nemethova M, Fando JL, Salinas M: Role of protein synthesis in the ischemic tolerance acquisition induced by transient forebrain ischemia in the rat. Neurochem Res 2003, 28:1213-1219.

19. Smith ML, Bendek G, Dahlgren N, Rosen I, Wieloch T, Siesjo BK: Models for studying long-term recovery following forebrain ischemia in the rat. 2. A 2-vessel occlusion model. Acta Neurol Scand 1984, 69:385-401.

20. Thaddeus NS: Animal models of global cerebral ischemia. Acute stroke, bench to bedside New York: Informa HealthcareBhardwaj A, Alkayed NJ, Kirsch JR, Traystman RJ 2006, 275-292.

21. Dave KR, Lange-Asschenfeldt C, Raval AP, Prado R, Busto R, Saul I, PerezPinzon MA: Ischemic preconditioning ameliorates excitotoxicity by shifting glutamate/gamma-aminobutyric acid release and biosynthesis. $J$ Neurosci Res 2005, 82:665-673.

22. Hayashi T, Saito A, Okuno S, Ferrand-Drake M, Chan PH: Induction of GRP78 by ischemic preconditioning reduces endoplasmic reticulum stress and prevents delayed neuronal cell death. J Cereb Blood Flow Metab 2003, 23:949-961.

23. Liu C, Chen S, Kamme F, Hu BR: Ischemic preconditioning prevents protein aggregation after transient cerebral ischemia. Neuroscience 2005, 134:69-80.

24. Perez-Pinzon MA, Xu GP, Dietrich WD, Rosenthal M, Sick TJ: Rapid preconditioning protects rats against ischemic neuronal damage after 3 but not 7 days of reperfusion following global cerebral ischemia. J Cereb Blood Flow Metab 1997, 17:175-182.

25. Tatlisumak T, Li F, Fisher M: Animal models of ischemic stroke. Acute stroke, bench to bedside New York: Informa HealthcareBhardwaj A, Alkayed NJ, Kirsch JR, Traystman RJ 2006, 171-186.
26. Kirino T: Delayed neuronal death in the gerbil hippocampus following ischemia. Brain Res 1982, 239:57-69.

27. Kato H, Liu Y, Araki T, Kogure K: Temporal profile of the effects of pretreatment with brief cerebral ischemia on the neuronal damage following secondary ischemic insult in the gerbil: cumulative damage and protective effects. Brain Res 1991, 553:238-242.

28. Kirino T, Tsujita Y, Tamura A: Induced tolerance to ischemia in gerbil hippocampal neurons. J Cereb Blood Flow Metab 1991, 11:299-307.

29. Kato H, Kogure K, Nakata N, Araki T, Itoyama Y: Facilitated recovery from postischemic suppression of protein synthesis in the gerbil brain with ischemic tolerance. Brain Res Bull 1995, 36:205-208.

30. Corbett $D$, Crooks P: Ischemic preconditioning: a long term survival study using behavioural and histological endpoints. Brain Res 1997, 760:129-136.

31. Castro-Pacheco A, Foyo-Niembro E, Perez-Perez V, Garcia-Hernandez J, Grijalva I: [Carotid-basilar artery communication in gerbils (Meriones unguiculatus)]. Rev Neurol 2001, 32:225-228.

32. Ueda M, Nowak TS Jr: Protective preconditioning by transient global ischemia in the rat: components of delayed injury progression and lasting protection distinguished by comparisons of depolarization thresholds for cell loss at long survival times. J Cereb Blood Flow Metab 2005, 25:949-958.

33. Terashima T, Namura S, Hoshimaru M, Uemura Y, Kikuchi H, Hashimoto N: Consistent injury in the striatum of $\mathrm{C} 57 \mathrm{BL} / 6$ mice after transient bilateral common carotid artery occlusion. Neurosurgery 1998, 43:900-907.

34. Wu C, Zhan RZ, Qi S, Fujihara H, Taga K, Shimoji K: A forebrain ischemic preconditioning model established in C57Black/Crj6 mice. J Neurosci Methods 2001, 107:101-106.

35. Munoz A, Nakazaki M, Goodman JC, Barrios R, Onetti CG, Bryan J, AguilarBryan L: Ischemic preconditioning in the hippocampus of a knockout mouse lacking SUR1-based K(ATP) channels. Stroke 2003, 34:164-170.

36. Koizumi J, Yoshida Y, Nakazawa T, Ooneda G: Experimental studies of ischemic brain edema: 1. A new experimental model of cerebral embolism in rats in which recirculation can be introduced in the ischemic area. Jpn J Stroke 1986, 8:1-8.

37. Longa EZ, Weinstein PR, Carlson S, Cummins R: Reversible middle cerebral artery occlusion without craniectomy in rats. Stroke 1989, 20:84-91.

38. Takano K, Tatlisumak T, Bergmann AG, Gibson DG, Fisher M: Reproducibility and reliability of middle cerebral artery occlusion using a silicone-coated suture (Koizumi) in rats. J Neurol Sci 1997, 153:8-11.

39. Tatlisumak T, Carano RA, Takano K, Opgenorth TJ, Sotak CH, Fisher M: A novel endothelin antagonist, A-12 attenuates ischemic lesion size in rats with temporary middle cerebral artery occlusion: a diffusion and perfusion MRI study. Stroke 7722, 29:850-857.

40. Durukan A, Tatlisumak T: Acute ischemic stroke: overview of major experimental rodent models, pathophysiology, and therapy of focal cerebral ischemia. Pharmacol Biochem Behav 2007, 87:179-197.

41. Durukan A, Strbian D, Tatlisumak T: Rodent models of ischemic stroke: a useful tool for stroke drug development. Curr Pharm Des 2008, 14:359-370.

42. Huang Z, Huang PL, Panahian N, Dalkara T, Fishman MC, Moskowitz MA Effects of cerebral ischemia in mice deficient in neuronal nitric oxide synthase. Science 1994, 265:1883-1885.

43. Li J, Henman MC, Doyle KM, Strbian D, Kirby BP, Tatlisumak T, Shaw GG: The pre-ischaemic neuroprotective effect of a novel polyamine antagonist, N1-dansyl-spermine in a permanent focal cerebral ischaemia model in mice. Brain Res 2004, 1029:84-92.

44. Li J, Henman MC, Tatlisumak T, Shaw GG, Doyle KM: The pre-ischaemic neuroprotective effects of N1-dansyl-spermine in a transient focal cerebral ischaemia model in mice. Brain Res 2005, 1055:180-185.

45. Li J, Henman MC, Atkinson J, Fixon-Owoo S, Tatlisumak T, Shaw GG Doyle KM: The pre-ischaemic neuroprotective effects of the polyamine analogues BU43b and BU36b in permanent and transient focal cerebral ischaemia models in mice. Brain Res 2006, 1076:209-215.

46. Barone FC, White RF, Spera PA, Ellison J, Currie RW, Wang X, Feuerstein GZ: Ischemic preconditioning and brain tolerance: temporal histological and functional outcomes, protein synthesis requirement, and interleukin-1 receptor antagonist and early gene expression. Stroke 1998, 29:1937-1950.

47. Masada T, Hua Y, Xi G, Ennis SR, Keep RF: Attenuation of ischemic brain edema and cerebrovascular injury after ischemic preconditioning in the rat. J Cereb Blood Flow Metab 2001, 21:22-33. 
48. Pradillo JM, Romera C, Hurtado O, Cardenas A, Moro MA, Leza JC, Davalos A, Castillo J, Lorenzo P, Lizasoain I: TNFR1 upregulation mediates tolerance after brain ischemic preconditioning. J Cereb Blood Flow Metab 2005, 25:193-203.

49. Stagliano NE, Perez-Pinzon MA, Moskowitz MA, Huang PL: Focal ischemic preconditioning induces rapid tolerance to middle cerebral artery occlusion in mice. J Cereb Blood Flow Metab 1999, 19:757-761.

50. Atochin DN, Clark J, Demchenko IT, Moskowitz MA, Huang PL: Rapid cerebral ischemic preconditioning in mice deficient in endothelial and neuronal nitric oxide synthases. Stroke 2003, 34:1299-1303.

51. Hao Y, Luo Z, Zhou D, Gao L: Cerebral ischemic tolerance induced by focal ischemic preconditioning in rats. Sichuan Da Xue Xue Bao Yi Xue Ban 2003, 34:455-458.

52. Lee SH, Kim YJ, Lee KM, Ryu S, Yoon BW: Ischemic preconditioning enhances neurogenesis in the subventricular zone. Neuroscience 2007, 146:1020-1031.

53. Alkayed NJ, Goyagi T, Joh HD, Klaus J, Harder DR, Traystman RJ, Hurn PD: Neuroprotection and P450 2C11 upregulation after experimental transient ischemic attack. Stroke 2002, 33:1677-1684.

54. Chen J, Graham SH, Zhu RL, Simon RP: Stress proteins and tolerance to focal cerebral ischemia. J Cereb Blood Flow Metab 1996, 16:566-577.

55. Li W, Luo Y, Zhang F, Signore AP, Gobbel GT, Simon RP, Chen J: Ischemic preconditioning in the rat brain enhances the repair of endogenous oxidative DNA damage by activating the base-excision repair pathway. J Cereb Blood Flow Metab 2006, 26:181-198.

56. Glantz L, Avramovich A, Trembovler V, Gurvitz V, Kohen R, Eidelman LA, Shohami E: Ischemic preconditioning increases antioxidants in the brain and peripheral organs after cerebral ischemia. Exp Neurol 2005, 192:117-124.

57. Puisieux F, Deplanque D, Bulckaen H, Maboudou P, Gele P, Lhermitte M, Lebuffe $G$, Bordet $R$ : Brain ischemic preconditioning is abolished by antioxidant drugs but does not up-regulate superoxide dismutase and glutathion peroxidase. Brain Res 2004, 1027:30-37.

58. Hoyte LC, Papadakis M, Barber PA, Buchan AM: Improved regional cerebral blood flow is important for the protection seen in a mouse model of late phase ischemic preconditioning. Brain Res 2006, 1121:231-237.

59. Naylor M, Bowen KK, Sailor KA, Dempsey RJ, Vemuganti R: Preconditioninginduced ischemic tolerance stimulates growth factor expression and neurogenesis in adult rat hippocampus. Neurochem Int 2005, 47:565-572.

60. Simon RP, Niiro $M$, Gwinn R: Prior ischemic stress protects against experimental stroke. Neurosci Lett 1993, 163:135-137.

61. Matsushima K, Hakim AM: Transient forebrain ischemia protects against subsequent focal cerebral ischemia without changing cerebral perfusion. Stroke 1995, 26:1047-1052.

62. Miyashita K, Abe H, Nakajima T, Ishikawa A, Nishiura M, Sawada T, Naritomi $\mathrm{H}$ : Induction of ischaemic tolerance in gerbil hippocampus by pretreatment with focal ischaemia. Neuroreport 1994, 6:46-48.

63. Belayev L, Ginsberg MD, Alonso OF, Singer JT, Zhao W, Busto R: Bilateral ischemic tolerance of rat hippocampus induced by prior unilateral transient focal ischemia: relationship to c-fos mRNA expression. Neuroreport 1996, 8:55-59.

64. Glazier SS, O'Rourke DM, Graham DI, Welsh FA: Induction of ischemic tolerance following brief focal ischemia in rat brain. J Cereb Blood Flow Metab 1994, 14:545-553.

65. Gidday JM, Fitzgibbons JC, Shah AR, Park TS: Neuroprotection from ischemic brain injury by hypoxic preconditioning in the neonatal rat. Neurosci Lett 1994, 168:221-224.

66. Miller BA, Perez RS, Shah AR, Gonzales ER, Park TS, Gidday JM: Cerebral protection by hypoxic preconditioning in a murine model of focal ischemia-reperfusion. Neuroreport 2001, 12:1663-1669.

67. Bernaudin M, Nedelec AS, Divoux D, MacKenzie ET, Petit E, SchumannBard P: Normobaric hypoxia induces tolerance to focal permanent cerebral ischemia in association with an increased expression of hypoxia-inducible factor- 1 and its target genes, erythropoietin and VEGF, in the adult mouse brain. J Cereb Blood Flow Metab 2002, 22:393-403.

68. Wada K, Ito M, Miyazawa T, Katoh H, Nawashiro H, Shima K, Chigasaki H: Repeated hyperbaric oxygen induces ischemic tolerance in gerbil hippocampus. Brain Res 1996, 740:15-20.

69. Prass K, Wiegand F, Schumann P, Ahrens M, Kapinya K, Harms C, Liao W, Trendelenburg G, Gertz K, Moskowitz MA, Knapp F, Victorov IV, Megow D,
Dirnagl U: Hyperbaric oxygenation induced tolerance against focal cerebral ischemia in mice is strain dependent. Brain Res 2000, 871:146-150

70. Xiong L, Zhu Z, Dong H, Hu W, Hou L, Chen S: Hyperbaric oxygen preconditioning induces neuroprotection against ischemia in transient not permanent middle cerebral artery occlusion rat model. Chin Med J (Engl) 2000, 113:836-839.

71. Hirata T, Cui YJ, Funakoshi T, Mizukami Y, Ishikawa Y, Shibasaki F, Matsumoto M, Sakabe T: The temporal profile of genomic responses and protein synthesis in ischemic tolerance of the rat brain induced by repeated hyperbaric oxygen. Brain Res 2007, 1130:214-222.

72. Chopp M, Chen H, Ho KL, Dereski MO, Brown E, Hetzel FW, Welch KM: Transient hyperthermia protects against subsequent forebrain ischemic cell damage in the rat. Neurology 1989, 39:1396-1398.

73. Ikeda $T$, Xia XY, Xia YX, Ikenoue T: Hyperthermic preconditioning prevents blood-brain barrier disruption produced by hypoxia-ischemia in newborn rat. Brain Res Dev Brain Res 1999, 117:53-58.

74. Nishio S, Chen ZF, Yunoki M, Toyoda T, Anzivino M, Lee KS: Hypothermiainduced ischemic tolerance. Ann N Y Acad Sci 1999, 890:26-41.

75. Yunoki M, Nishio S, Ukita N, Anzivino MJ, Lee KS: Characteristics of hypothermic preconditioning influencing the induction of delayed ischemic tolerance. J Neurosurg 2002, 97:650-657.

76. Schwab S, Schwarz S, Spranger M, Keller E, Bertram M, Hacke W: Moderate hypothermia in the treatment of patients with severe middle cerebral artery infarction. Stroke 1998, 29:2461-2466.

77. Tatlisumak T, Takano K, Meiler MR, Fisher M: A glycine site antagonist, ZD reduces number of spreading depressions and infarct size in rats with permanent middle cerebral artery occlusion. Stroke 9379, 29:190-195.

78. Jander S, Schroeter M, Peters O, Witte OW, Stoll G: Cortical spreading depression induces proinflammatory cytokine gene expression in the rat brain. J Cereb Blood Flow Metab 2001, 21:218-225.

79. Kawahara N, Ruetzler CA, Klatzo I: Protective effect of spreading depression against neuronal damage following cardiac arrest cerebral ischaemia. Neurol Res 1995, 17:9-16.

80. Matsushima K, Hogan MJ, Hakim AM: Cortical spreading depression protects against subsequent focal cerebral ischemia in rats. J Cereb Blood Flow Metab 1996, 16:221-226.

81. Horiguchi T, Snipes JA, Kis B, Shimizu K, Busija DW: The role of nitric oxide in the development of cortical spreading depression-induced tolerance to transient focal cerebral ischemia in rats. Brain Res 2005, 1039:84-89.

82. Otori T, Greenberg JH, Welsh FA: Cortical spreading depression causes a long-lasting decrease in cerebral blood flow and induces tolerance to permanent focal ischemia in rat brain. J Cereb Blood Flow Metab 2003, 23:43-50.

83. Horiguchi T, Snipes JA, Kis B, Shimizu K, Busija DW: Cyclooxygenase-2 mediates the development of cortical spreading depression-induced tolerance to transient focal cerebral ischemia in rats. Neuroscience 2006, 140:723-730.

84. Yanamoto H, Xue JH, Miyamoto S, Nagata I, Nakano Y, Murao K, Kikuchi H: Spreading depression induces long-lasting brain protection against infarcted lesion development via BDNF gene-dependent mechanism. Brain Res 2004, 1019:178-188.

85. Yanamoto H, Hashimoto N, Nagata I, Kikuchi H: Infarct tolerance against temporary focal ischemia following spreading depression in rat brain. Brain Res 1998, 784:239-249.

86. Sun XC, Li WB, Li QJ, Zhang M, Xian XH, Qi J, Jin RL, Li SQ: Limb ischemic preconditioning induces brain ischemic tolerance via p38 MAPK. Brain Res 2006, 1084:165-174.

87. Zhao HG, Sun XC, Xian XH, Li WB, Zhang M, Li QJ: The role of nitric oxide in the neuroprotection of limb ischemic preconditioning in rats. Neurochem Res 2007, 32:1919-1926.

88. Ali ZA, Callaghan CJ, Lim E, Ali AA, Nouraei SA, Akthar AM, Boyle JR, Varty K, Kharbanda RK, Dutka DP, Gaunt ME: Remote ischemic preconditioning reduces myocardial and renal injury after elective abdominal aortic aneurysm repair: a randomized controlled trial. Circulation 2007, 116: 198-105.

89. Rehni AK, Shri $R$, Singh M: Remote ischaemic preconditioning and prevention of cerebral injury. Indian J Exp Biol 2007, 45:247-252.

90. Wiegand F, Liao W, Busch C, Castell S, Knapp F, Lindauer U, Megow D, Meisel A, Redetzky A, Ruscher K, Trendelenburg G, Victorov I, Riepe M, 
Diener HC, Dirnagl U: Respiratory chain inhibition induces tolerance to focal cerebral ischemia. J Cereb Blood Flow Metab 1999, 19:1229-1237.

91. Zhu HC, Gao XQ, Xing Y, Sun SG, Li HG, Wang YF: Inhibition of caspase-3 activation and apoptosis is involved in 3-nitropropionic acid-induced ischemic tolerance to transient focal cerebral ischemia in rats. $J \mathrm{Mol}$ Neurosci 2004, 24:299-305.

92. Zhu H, Sun S, Li H, Xu Y: Cerebral ischemic tolerance induced by 3nitropropionic acid is associated with increased expression of erythropoietin in rats. J Huazhong Univ Sci Technolog Med Sci 2006, 26:440-443.

93. Horiguchi T, Kis B, Rajapakse N, Shimizu K, Busija DW: Opening of mitochondrial ATP-sensitive potassium channels is a trigger of 3 nitropropionic acid-induced tolerance to transient focal cerebral ischemia in rats. Stroke 2003, 34:1015-1020.

94. Garnier P, Bertrand N, Demougeot C, Prigent-Tessier A, Marie C, Beley A: Chemical preconditioning with 3-nitropropionic acid: lack of induction of neuronal tolerance in gerbil hippocampus subjected to transient forebrain ischemia. Brain Res Bull 2002, 58:33-39.

95. Sugino T, Nozaki K, Takagi Y, Hashimoto N: 3-Nitropropionic acid induces ischemic tolerance in gerbil hippocampus in vivo. Neurosci Lett 1999, 259:9-12.

96. Kato K, Shimazaki K, Kamiya T, Amemiya S, Inaba T, Oguro K, Katayama Y: Differential effects of sublethal ischemia and chemical preconditioning with 3-nitropropionic acid on protein expression in gerbil hippocampus. Life Sci 2005, 77:2867-2878.

97. Hoshi A, Nakahara T, Ogata M, Yamamoto T: The critical threshold of 3nitropropionic acid-induced ischemic tolerance in the rat. Brain Res 2005, 1050:33-39.

98. Bordet R, Deplanque D, Maboudou P, Puisieux F, Pu Q, Robin E, Martin A, Bastide $M$, Leys $D$, Lhermitte $M$, Dupuis $B$ : Increase in endogenous brain superoxide dismutase as a potential mechanism of lipopolysaccharideinduced brain ischemic tolerance. I Cereb Blood Flow Metab 2000, 20:1190-1196.

99. Bastide M, Gele P, Petrault O, Pu Q, Caliez A, Robin E, Deplanque D, Duriez $P$, Bordet R: Delayed cerebrovascular protective effect of lipopolysaccharide in parallel to brain ischemic tolerance. J Cereb Blood Flow Metab 2003, 23:399-405.

100. Dawson DA, Furuya K, Gotoh J, Nakao Y, Hallenbeck JM: Cerebrovascular hemodynamics and ischemic tolerance: lipopolysaccharide-induced resistance to focal cerebral ischemia is not due to changes in severity of the initial ischemic insult, but is associated with preservation of microvascular perfusion. J Cereb Blood Flow Metab 1999, 19:616-623.

101. Tasaki K, Ruetzler CA, Ohtsuki T, Martin D, Nawashiro H, Hallenbeck JM: Lipopolysaccharide pre-treatment induces resistance against subsequent focal cerebral ischemic damage in spontaneously hypertensive rats. Brain Res 1997, 748:267-270.

102. Rosenzweig HL, Lessov NS, Henshall DC, Minami M, Simon RP, StenzelPoore MP: Endotoxin preconditioning prevents cellular inflammatory response during ischemic neuroprotection in mice. Stroke 2004, 35:2576-2581.

103. Wang L, Traystman RJ, Murphy SJ: Inhalational anesthetics as preconditioning agents in ischemic brain. Curr Opin Pharmacol 2008 8:104-110.

104. Kitano H, Kirsch JR, Hurn PD, Murphy SJ: Inhalational anesthetics as neuroprotectants or chemical preconditioning agents in ischemic brain J Cereb Blood Flow Metab 2007, 27:1108-1128.

105. Clarkson AN: Anesthetic-mediated protection/preconditioning during cerebral ischemia. Life Sci 2007, 80:1157-1175.

106. Blanck TJ, Haile M, Xu F, Zhang J, Heerdt P, Veselis RA, Beckman J, Kang R, Adamo A, Hemmings $\mathrm{H}$ : Isoflurane pretreatment ameliorates postischemic neurologic dysfunction and preserves hippocampal $\mathrm{Ca} 2$ +/calmodulin-dependent protein kinase in a canine cardiac arrest model. Anesthesiology 2000, 93:1285-1293.

107. Liu Y, Xiong L, Chen S, Wang Q: Isoflurane tolerance against focal cerebral ischemia is attenuated by adenosine $\mathrm{A} 1$ receptor antagonists. Can J Anaesth 2006, 53:194-201.

108. Zheng S, Zuo Z: Isoflurane preconditioning induces neuroprotection against ischemia via activation of P38 mitogen-activated protein kinases. Mol Pharmacol 2004, 65:1172-1180.
109. McAuliffe JJ, Joseph B, Vorhees CV: Isoflurane-delayed preconditioning reduces immediate mortality and improves striatal function in adult mice after neonatal hypoxia-ischemia. Anesth Analg 2007, 104:1066-1077.

110. Zheng S, Zuo Z: Isoflurane preconditioning reduces purkinje cell death in an in vitro model of rat cerebellar ischemia. Neuroscience 2003, 118:99-106.

111. Kaneko T, Yokoyama K, Makita K: Late preconditioning with isoflurane in cultured rat cortical neurones. Br J Anaesth 2005, 95:662-668.

112. Ma D, Hossain M, Pettet GK, Luo Y, Lim T, Akimov S, Sanders RD, Franks NP, Maze $\mathrm{M}$ : Xenon preconditioning reduces brain damage from neonatal asphyxia in rats. J Cereb Blood Flow Metab 2006, 26:199-208.

113. Kapinya KJ, Lowl D, Futterer C, Maurer M, Waschke KF, Isaev NK, Dirnagl U: Tolerance against ischemic neuronal injury can be induced by volatile anesthetics and is inducible NO synthase dependent. Stroke 2002, 33:1889-1898.

114. Payne RS, Akca O, Roewer N, Schurr A, Kehl F: Sevoflurane-induced preconditioning protects against cerebral ischemic neuronal damage in rats. Brain Res 2005, 1034:147-152.

115. Frassdorf J, Borowski A, Ebel D, Feindt P, Hermes M, Meemann T, Weber R, Mullenheim J, Weber NC, Preckel B, Schlack W: Impact of preconditioning protocol on anesthetic-induced cardioprotection in patients having coronary artery bypass surgery. I Thorac Cardiovasc Surg 2009, 137:1436-1442

116. Raval AP, Bramlett H, Perez-Pinzon MA: Estrogen preconditioning protects the hippocampal CA1 against ischemia. Neuroscience 2006, 141:1721-1730.

117. Brambrink AM, Koerner IP, Diehl K, Strobel G, Noppens R, Kempski O: The antibiotic erythromycin induces tolerance against transient global cerebral ischemia in rats (pharmacologic preconditioning). Anesthesiology 2006, 104:1208-1215

118. Koerner IP, Gatting M, Noppens R, Kempski O, Brambrink AM: Induction of cerebral ischemic tolerance by erythromycin preconditioning reprograms the transcriptional response to ischemia and suppresses inflammation. Anesthesiology 2007, 106:538-547.

119. Ruscher K, Freyer D, Karsch M, Isaev N, Megow D, Sawitzki B, Priller J, Dirnagl U, Meisel A: Erythropoietin is a paracrine mediator of ischemic tolerance in the brain: evidence from an in vitro model. J Neurosci 2002, 22:10291-10301.

120. Bernaudin M, Marti HH, Roussel S, Divoux D, Nouvelot A, MacKenzie ET, Petit E: A potential role for erythropoietin in focal permanent cerebral ischemia in mice. J Cereb Blood Flow Metab 1999, 19:643-651.

121. Riepe MW, Kasischke K, Raupach A: Acetylsalicylic acid increases tolerance against hypoxic and chemical hypoxia. Stroke 1997, 28:2006-2011.

122. Huber R, Kasischke K, Ludolph AC, Riepe MW: Increase of cellular hypoxic tolerance by erythromycin and other antibiotics. Neuroreport 1999, 10:1543-1546.

123. Xiong L, Lu Z, Hou L, Zheng H, Zhu Z, Wang Q, Chen S: Pretreatment with repeated electroacupuncture attenuates transient focal cerebral ischemic injury in rats. Chin Med J (Engl) 2003, 116:108-111.

124. Xiong LZ, Yang J, Wang Q, Lu ZH: Involvement of delta-and mu-opioid receptors in the delayed cerebral ischemic tolerance induced by repeated electroacupuncture preconditioning in rats. Chin Med J (Engl) 2007, 120:394-399

125. Reis DJ, Kobylarz K, Yamamoto S, Golanov EV: Brief electrical stimulation of cerebellar fastigial nucleus conditions long-lasting salvage from focal cerebral ischemia: conditioned central neurogenic neuroprotection. Brain Res 1998, 780:161-165.

126. Yu ZF, Mattson MP: Dietary restriction and 2-deoxyglucose administration reduce focal ischemic brain damage and improve behavioral outcome: evidence for a preconditioning mechanism. J Neurosci Res 1999, 57:830-839.

127. Ogiue-lkeda M, Kawato S, Ueno S: Acquisition of ischemic tolerance by repetitive transcranial magnetic stimulation in the rat hippocampus. Brain Res 2005, 1037:7-11.

128. Mishima Y, Harada H, Sugiyama K, Miyagawa Y, Uehara N, Kano T: Induction of neuronal tolerance by electroconvulsive shock in rats subjected to forebrain ischemia. Kurume Med J 2005, 52:153-160.

129. Plamondon H, Blondeau N, Heurteaux C, Lazdunski M: Mutually protective actions of kainic acid epileptic preconditioning and sublethal global ischemia on hippocampal neuronal death: involvement of adenosine A1 receptors and K(ATP) channels. J Cereb Blood Flow Metab 1999, 19:1296-1308. 
130. Hsu JC, Lee YS, Chang CN, Ling EA, Lan CT: Sleep deprivation prior to transient global cerebral ischemia attenuates glial reaction in the rat hippocampal formation. Brain Res 2003, 984:170-181.

131. Gonzalez-Zulueta M, Feldman AB, Klesse LJ, Kalb RG, Dillman JF, Parada LF, Dawson TM, Dawson VL: Requirement for nitric oxide activation of p21 (ras)/extracellular regulated kinase in neuronal ischemic preconditioning. Proc Natl Acad Sci USA 2000, 97:436-441.

132. Goldberg MP, Choi DW: Combined oxygen and glucose deprivation in cortical cell culture: calcium-dependent and calcium-independent mechanisms of neuronal injury. J Neurosci 1993, 13:3510-3524.

133. Kapinya KJ: Ischemic tolerance in the brain. Acta Physiol Hung 2005, 92:67-92.

134. Valentim LM, Rodnight $R$, Geyer AB, Horn AP, Tavares A, Cimarosti $H$, Netto CA, Salbego CG: Changes in heat shock protein 27 phosphorylation and immunocontent in response to preconditioning to oxygen and glucose deprivation in organotypic hippocampal cultures. Neuroscience 2003, 118:379-386.

135. Hassen GW, Tian D, Ding D, Bergold PJ: A new model of ischemic preconditioning using young adult hippocampal slice cultures. Brain Res Brain Res Protoc 2004, 13:135-143.

136. Grabb MC, Choi DW: Ischemic tolerance in murine cortical cell culture: critical role for NMDA receptors. J Neurosci 1999, 19:1657-1662.

137. Sommer C: Ischemic preconditioning: postischemic structural changes in the brain. J Neuropathol Exp Neurol 2008, 67:85-92.

138. Corbett D, Nurse $S$ : The problem of assessing effective neuroprotection in experimental cerebral ischemia. Prog Neurobiol 1998, 54:531-548.

139. Tatlisumak T, Takano K, Carano RA, Fisher M: Effect of basic fibroblast growth factor on experimental focal ischemia studied by diffusionweighted and perfusion imaging. Stroke 1996, 27:2292-2297.

140. Takano K, Carano RA, Tatlisumak T, Meiler M, Sotak CH, Kleinert HD, Fisher M: Efficacy of intra-arterial and intravenous prourokinase in an embolic stroke model evaluated by diffusion-perfusion magnetic resonance imaging. Neurology 1998, 50:870-875.

141. Tanaka H, Calderone A, Jover T, Grooms SY, Yokota H, Zukin RS, Bennett MV: Ischemic preconditioning acts upstream of GluR2 downregulation to afford neuroprotection in the hippocampal CA1. Proc Natl Acad Sci USA 2002, 99:2362-2367.

142. Ostrowski RP, Graupner G, Titova E, Zhang J, Chiu J, Dach N, Corleone D, Tang J, Zhang JH: The hyperbaric oxygen preconditioning-induced brain protection is mediated by a reduction of early apoptosis after transient global cerebral ischemia. Neurobiol Dis 2007, 29:1-13.

143. Kim E, Raval AP, Defazio RA, Perez-Pinzon MA: Ischemic preconditioning via epsilon protein kinase $C$ activation requires cyclooxygenase-2 activation in vitro. Neuroscience 2007, 145:931-941.

144. Menzies SA, Hoff JT, Betz AL: Middle cerebral artery occlusion in rats: a neurological and pathological evaluation of a reproducible model. Neurosurgery 1992, 31:100-106.

145. Hunter AJ, Hatcher J, Virley D, Nelson P, Irving E, Hadingham SJ, Parsons AA: Functional assessments in mice and rats after focal stroke. Neuropharmacology 2000, 39:806-816.

146. Nunn J, Hodges $\mathrm{H}$ : Cognitive deficits induced by global cerebral ischaemia: relationship to brain damage and reversal by transplants. Behav Brain Res 1994, 65:1-31.

147. Tatlisumak T, Li F: Use of diffusion- and perfusion-weighted magnetic resonance imaging in drug development for ischemic stroke. Curr Drug Targets CNS Neurol Disord 2003, 2:131-141.

148. Tatlisumak T, Strbian D, Abo Ramadan U, Li F: The role of diffusion- and perfusion-weighted magnetic resonance imaging in drug development for ischemic stroke: from laboratory to clinics. Curr Vasc Pharmacol 2004, 2:343-355

149. Durukan A, Tatlisumak T: Magnetic resonance imaging in drug development for ischemic stroke: a translational approach. Drug Design Research Perspectives NY: Nova Science Pub IncKaplan SP 2007, 171-211.

150. Strbian D, Durukan A, Pitkonen M, Marinkovic I, Tatlisumak E, Pedrono E, Abo-Ramadan U, Tatlisumak T: The blood-brain barrier is continuously open for several weeks following transient focal cerebral ischemia. Neuroscience 2008, 153:175-181.

151. Durukan A, Marinkovic I, Strbian D, Pitkonen M, Pedrono E, Soinne L, AboRamadan U, Tatlisumak T: Post-ischemic blood-brain barrier leakage in rats: one-week follow-up by MRI. Brain Res 2009, 1280:158-165.
152. Mullins PG, Reid DG, Hockings PD, Hadingham SJ, Campbell CA, Chalk JB, Doddrell DM: Ischaemic preconditioning in the rat brain: a longitudinal magnetic resonance imaging (MRI) study. NMR Biomed 2001, 14:204-209.

153. Tatlisumak T, Carano RA, Takano K, Meiler MR, Li F, Sotak CH, Arndts D, Pschorn U, Fisher M: Broad-spectrum cation channel inhibition by LOE 908 MS reduces infarct volume in vivo and postmortem in focal cerebral ischemia in the rat. J Neurol Sci 2000, 178:107-113.

154. Carano RA, Li F, Irie K, Helmer KG, Silva MD, Fisher M, Sotak CH: Multispectral analysis of the temporal evolution of cerebral ischemia in the rat brain. J Magn Reson Imaging 2000, 12:842-858.

155. Li F, Carano RA, Irie K, Tatlisumak T, Silva MD, Pschorni U, Sotak CH, Fisher M: Neuroprotective effects of a novel broad-spectrum cation channel blocker, LOE 908 MS, on experimental focal ischemia: a multispectral study. J Magn Reson Imaging 1999, 10:138-145.

156. Furuya K, Zhu L, Kawahara N, Abe O, Kirino T: Differences in infarct evolution between lipopolysaccharide-induced tolerant and nontolerant conditions to focal cerebral ischemia. J Neurosurg 2005, 103:715-723.

157. Gustavsson M, Wilson MA, Mallard C, Rousset C, Johnston MV, Hagberg H: Global gene expression in the developing rat brain after hypoxic preconditioning: involvement of apoptotic mechanisms?. Pediatr Res 2007, 61:444-450.

158. Dhodda VK, Sailor KA, Bowen KK, Vemuganti R: Putative endogenous mediators of preconditioning-induced ischemic tolerance in rat brain identified by genomic and proteomic analysis. J Neurochem 2004, 89:73-89.

159. Kato $H$, Araki T, Kogure K: Preserved neurotransmitter receptor binding following ischemia in preconditioned gerbil brain. Brain Res Bull 1992, 29:395-400.

160. Sommer $C$, Fahrner A, Kiessling M: [3H]muscimol binding to gammaaminobutyric $\operatorname{acid}(A)$ receptors is upregulated in CA1 neurons of the gerbil hippocampus in the ischemia-tolerant state. Stroke 2002, 33:1698-1705.

161. Nakagomi T, Kirino T, Kanemitsu H, Tsujita Y, Tamura A: Early recovery of protein synthesis following ischemia in hippocampal neurons with induced tolerance in the gerbil. Acta Neuropathol 1993, 86:10-15.

162. Nishimura M, Sugino T, Nozaki K, Takagi Y, Hattori I, Hayashi J, Hashimoto N, Moriguchi T, Nishida E: Activation of p38 kinase in the gerbil hippocampus showing ischemic tolerance. J Cereb Blood Flow Metab 2003, 23:1052-1059.

163. Cho S, Park EM, Zhou P, Frys K, Ross ME, ladecola C: Obligatory role of inducible nitric oxide synthase in ischemic preconditioning. J Cereb Blood Flow Metab 2005, 25:493-501.

164. Kunz A, Park L, Abe T, Gallo EF, Anrather J, Zhou P, ladecola C: Neurovascular protection by ischemic tolerance: role of nitric oxide and reactive oxygen species. J Neurosci 2007, 27:7083-7093.

165. Gidday JM, Shah AR, Maceren RG, Wang Q, Pelligrino DA, Holtzman DM, Park TS: Nitric oxide mediates cerebral ischemic tolerance in a neonatal rat model of hypoxic preconditioning. J Cereb Blood Flow Metab 1999, 19:331-340.

166. Centeno JM, Orti M, Salom JB, Sick TJ, Perez-Pinzon MA: Nitric oxide is involved in anoxic preconditioning neuroprotection in rat hippocampal slices. Brain Res 1999, 836:62-69.

167. Dirnagl U, Simon RP, Hallenbeck JM: Ischemic tolerance and endogenous neuroprotection. Trends Neurosci 2003, 26:248-254

168. Dirnagl U, Meisel A: Endogenous neuroprotection: mitochondria as gateways to cerebral preconditioning?. Neuropharmacology 2008, 55:334-344.

169. Obrenovitch TP: Molecular physiology of preconditioning-induced brain tolerance to ischemia. Physiol Rev 2008, 88:211-247.

170. Bergeron M, Gidday JM, YU AY, Semenza GL, Ferriero DM, Sharp FR: Role of hypoxia-inducible factor-1 in hypoxia-induced ischemic tolerance in neonatal rat brain. Ann Neurol 2000, 48:285-296.

171. Ratan RR, Siddiq A, Aminova L, Lange PS, Langley B, Ayoub I, Gensert J, Chavez J: Translation of ischemic preconditioning to the patient: prolyl hydroxylase inhibition and hypoxia inducible factor- 1 as novel targets for stroke therapy. Stroke 2004, 35:2687-2689.

172. Sharp FR, Ran R, Lu A, Tang Y, Strauss Kl, Glass T, Ardizzone T, Bernaudin M: Hypoxic preconditioning protects against ischemic brain injury. NeuroRx 2004, 1:26-35.

173. Tang Y, Pacary E, Freret T, Divoux D, Petit E, Schumann-Bard P, Bernaudin M: Effect of hypoxic preconditioning on brain genomic 
response before and following ischemia in the adult mouse: identification of potential neuroprotective candidates for stroke. Neurobiol Dis 2006, 21:18-28.

174. Bright $R$, Mochly-Rosen D: The role of protein kinase $C$ in cerebral ischemic and reperfusion injury. Stroke 2005, 36:2781-2790.

175. Tauskela JS, chakravarthy BR, Murray CL, Wang Y, Comas T, Hogan M, Hakim A, Morley P: Evidence from cultured rat cortical neurons of differences in the mechanism of ischemic preconditioning of brain and heart. Brain Res 1999, 827:143-151.

176. Perez-Pinzon MA, Born JG: Rapid preconditioning neuroprotection following anoxia in hippocampal slices: role of the K+ ATP channel and protein kinase C. Neuroscience 1999, 89:453-459.

177. Raval AP, Dave KR, Mochly-Rosen D, Sick TJ, Perez-Pinzon MA: Epsilon PKC is required for the induction of tolerance by ischemic and NMDAmediated preconditioning in the organotypic hippocampal slice. J Neurosci 2003, 23:384-391.

178. Lange-Asschenfeldt C, Raval AP, Dave KR, Mochly-Rosen D, Sick TJ, PerezPinzon MA: Epsilon protein kinase $C$ mediated ischemic tolerance requires activation of the extracellular regulated kinase pathway in the organotypic hippocampal slice. J Cereb Blood Flow Metab 2004, 24:636-645.

179. Tauskela JS, Comas T, Hewitt K, Monette R, Paris J, Hogan M, Morley P: Cross-tolerance to otherwise lethal N-methyl-D-aspartate and oxygenglucose deprivation in preconditioned cortical cultures. Neuroscience 2001, 107:571-584

180. Bond A, Lodge D, Hicks CA, Ward MA, O'Neill MJ: NMDA receptor antagonism, but not AMPA receptor antagonism attenuates induced ischaemic tolerance in the gerbil hippocampus. Eur J Pharmacol 1999, 380:91-99.

181. Wang RM, Yang F, Zhang YX: Preconditioning-induced activation of ERK5 is dependent on moderate $\mathrm{Ca} 2+$ influx via NMDA receptors and contributes to ischemic tolerance in the hippocampal CA1 region of rats. Life Sci 2006, 79:1839-1846

182. Duszczyk M, Gadamski R, Ziembowicz A, Danysz W, Lazarewicz JW: NMDA receptor antagonism does not inhibit induction of ischemic tolerance in gerbil brain in vivo. Neurotox Res 2005, 7:283-292.

183. Lange-Asschenfeldt C, Raval AP, Perez-Pinzon MA: Ischemic tolerance induction in organotypic hippocampal slices: role for the GABA(A) receptor?. Neurosci Lett 2005, 384:87-92.

184. Tauskela JS, Morley P: On the role of $\mathrm{Ca} 2+$ in cerebral ischemic preconditioning. Cell Calcium 2004, 36:313-322.

185. Pong K: Ischaemic preconditioning: therapeutic implications for stroke? Expert Opin Ther Targets 2004, 8:125-139.

186. Rodrigo GC, Standen NB: ATP-sensitive potassium channels. Curr Pharm Des 2005, 11:1915-1940.

187. Heurteaux C, Lauritzen I, Widmann C, Lazdunski M: Essential role of adenosine, adenosine $\mathrm{A} 1$ receptors, and ATP-sensitive $\mathrm{K}+$ channels in cerebral ischemic preconditioning. Proc Natl Acad Sci USA 1995, 92:4666-4670.

188. Reshef A, Sperling O, Zoref-Shani E: Opening of K(ATP) channels is mandatory for acquisition of ischemic tolerance by adenosine. Neuroreport 2000, 11:463-465.

189. Hiraide T, Katsura K, Muramatsu H, Asano G, Katayama Y: Adenosine receptor antagonists cancelled the ischemic tolerance phenomenon in gerbil. Brain Res 2001, 910:94-98.

190. Yoshida M, Nakakimura K, Cui YJ, Matsumoto M, Sakabe T: Adenosine A(1) receptor antagonist and mitochondrial ATP-sensitive potassium channel blocker attenuate the tolerance to focal cerebral ischemia in rats. J Cereb Blood Flow Metab 2004, 24:771-779.

191. Horiguchi T, Kis B, Rajapakse N, Shimizu K, Busija DW: Cortical spreading depression (CSD)-induced tolerance to transient focal cerebral ischemia in halothane anesthetized rats is affected by anesthetic level but not ATP-sensitive potassium channels. Brain Res 2005, 1062:127-133.

192. Nandagopal K, Dawson TM, Dawson VL: Critical role for nitric oxide signaling in cardiac and neuronal ischemic preconditioning and tolerance. J Pharmacol Exp Ther 2001, 297:474-478.

193. Huang PL: Nitric oxide and cerebral ischemic preconditioning. Cell Calcium 2004, 36:323-329.

194. PuisieuX F, Deplanque D, Pu Q, Souil E, Bastide M, Bordet R: Differential role of nitric oxide pathway and heat shock protein in preconditioning and lipopolysaccharide-induced brain ischemic tolerance. Eur J Pharmacol 2000, 389:71-78.

195. Zimmermann C, Ginis I, Furuya K, Klimanis D, Ruetzler C, Spatz M, Hallenbeck JM: Lipopolysaccharide-induced ischemic tolerance is associated with increased levels of ceramide in brain and in plasma. Brain Res 2001, 895:59-65.

196. Lastres-Becker I, Cartmell T, Molina-Holgado F: Endotoxin preconditioning protects neurones from in vitro ischemia: role of endogenous IL-1beta and TNF-alpha. J Neuroimmunol 2006, 173:108-116.

197. Ohtsuki T, Ruetzler CA, Tasaki K, Hallenbeck JM: Interleukin-1 mediates induction of tolerance to global ischemia in gerbil hippocampal CA1 neurons. J Cereb Blood Flow Metab 1996, 16:1137-1142.

198. Cardenas A, Moro MA, Leza JC, O'Shea E, Davalos A, Castillo J, Lorenzo P, Lizasoain I: Upregulation of TACE/ADAM17 after ischemic preconditioning is involved in brain tolerance. $J$ Cereb Blood Flow Metab 2002, 22:1297-1302.

199. Bouwmeester T, Bauch A, Ruffner H, Angrand PO, Bergamini G, Croughton K, Cruciat C, Eberhard D, Gagneur J, Ghidelli S, Hopf C, Huhse B, Mangano R, Michon AM, Schirle M, Schlegl J, Schwab M, Stein MA, Bauer A, Casari G, Drewes G, Gavin AC, Jackson DB, Joberty G, Neubauer G, Rick J, Kuster B, Superti-Furga G: A physical and functional map of the human TNF-alpha/NF-kappa B signal transduction pathway. Nat Cell Biol 2004, 6:97-105.

200. Blondeau N, Widmann C, Lazdunski M, Heurteaux C: Activation of the nuclear factor-kappaB is a key event in brain tolerance. J Neurosci 2001, 21:4668-4677.

201. Digicaylioglu M, Lipton SA: Erythropoietin-mediated neuroprotection involves cross-talk between Jak2 and NF-kappaB signalling cascades. Nature 2001, 412:641-647.

202. Marsh BJ, Williams-Karnesky RL, Stenzel-Poore MP: Toll-like receptor signaling in endogenous neuroprotection and stroke. Neuroscience 2009 158:1007-1020

203. Bonni A, Brunet A, West AE, Datta SR, Takasu MA, Greenberg ME: Cell survival promoted by the Ras-MAPK signaling pathway by transcriptiondependent and -independent mechanisms. Science 1999, 286:1358-1362.

204. Miao B, Yin XH, Pei DS, Zhang QG, Zhang GY: Neuroprotective effects of preconditioning ischemia on ischemic brain injury through downregulating activation of JNK $1 / 2$ via $\mathrm{N}$-methyl-D-aspartate receptormediated Akt1 activation. J Biol Chem 2005, 280:21693-21699.

205. Zhang Y, Park TS, Gidday JM: Hypoxic preconditioning protects human brain endothelium from ischemic apoptosis by Akt-dependent survivin activation. Am J Physiol Heart Circ Physiol 2007, 292:H2573-2581.

206. Nakajima T, Iwabuchi S, Miyazaki H, Okuma Y, Kuwabara M, Nomura Y Kawahara K: Preconditioning prevents ischemia-induced neuronal death through persistent Akt activation in the penumbra region of the rat brain. J Vet Med Sci 2004, 66:521-527.

207. Stenzel-Poore MP, Stevens SL, Xiong Z, Lessov NS, Harrington CA, Mori M, Meller R, Rosenzweig HL, Tobar E, Shaw TE, Chu X, Simon RP: Effect of ischaemic preconditioning on genomic response to cerebral ischaemia: similarity to neuroprotective strategies in hibernation and hypoxiatolerant states. Lancet 2003, 362:1028-1037.

208. Stenzel-Poore MP, Stevens SL, Simon RP: Genomics of preconditioning. Stroke 2004, 35:2683-2686.

209. Stenzel-Poore MP, Stevens SL, King JS, Simon RP: Preconditioning reprograms the response to ischemic injury and primes the emergence of unique endogenous neuroprotective phenotypes: a speculative synthesis. Stroke 2007, 38:680-685.

210. Stevens SL, Stenzel-Poore MP: Toll-like receptors and tolerance to ischaemic injury in the brain. Biochem Soc Trans 2006, 34:1352-1355.

211. Nakamura M, Nakakimura K, Matsumoto M, Sakabe T: Rapid tolerance to focal cerebral ischemia in rats is attenuated by adenosine $A 1$ receptor antagonist. J Cereb Blood Flow Metab 2002, 22:161-170.

212. Truettner J, Busto R, Zhao W, Ginsberg MD, Perez-Pinzon MA: Effect of ischemic preconditioning on the expression of putative neuroprotective genes in the rat brain. Brain Res Mol Brain Res 2002, 103:106-115.

213. Kariko K, Weissman D, Welsh FA: Inhibition of toll-like receptor and cytokine signaling-a unifying theme in ischemic tolerance. J Cereb Blood Flow Metab 2004, 24:1288-1304

214. Pera J, Zawadzka M, Kaminska B, Szczudlik A: Influence of chemical and ischemic preconditioning on cytokine expression after focal brain ischemia. J Neurosci Res 2004, 78:132-140. 
215. Pera J, Zawadzka M, Kaminska B, Szczudlik A: Neurotrophic factor expression after focal brain ischemia preceded by different preconditioning strategies. Cerebrovasc Dis 2005, 19:247-252.

216. Nyitrai G, Puskas L, Antal K, Takacs V, Sass M, Juhasz G, Kardos J, Palkovits M: Preconditioning-specific reduction of c-fos expression in hippocampal granule and pyramidal but not other forebrain neurons of ischemic brain: a quantitative immunohistochemical study. Neurosci Lett 2005, 381:344-349.

217. Alkayed NJ, Harukuni I, Kimes AS, London ED, Traystman RJ, Hurn PD: Gender-linked brain injury in experimental stroke. Stroke 1998, 29:159-165.

218. Gibson CL, Gray LJ, Murphy SP, Bath PM: Estrogens and experimental ischemic stroke: a systematic review. J Cereb Blood Flow Metab 2006, 26:1103-1113

219. Song X, Li G, Vaage J, Valen G: Effects of sex, gonadectomy, and oestrogen substitution on ischaemic preconditioning and ischaemiareperfusion injury in mice. Acta Physiol Scand 2003, 177:459-466.

220. Wang C, Chiari PC, Weihrauch D, Krolikowski JG, Warltier DC, Kersten JR, Pratt PF Jr, Pagel PS: Gender-specificity of delayed preconditioning by isoflurane in rabbits: potential role of endothelial nitric oxide synthase. Anesth Analg 2006, 103:274-280

221. Kitano H, Young JM, Cheng J, Wang L, Hurn PD, Murphy SJ: Genderspecific response to isoflurane preconditioning in focal cerebral ischemia. J Cereb Blood Flow Metab 2007, 27:1377-1386.

222. Dowden J, Corbett D: Ischemic preconditioning in 18- to 20-month-old gerbils: long-term survival with functional outcome measures. Stroke 1999, 30:1240-1246.

223. He Z, Crook JE, Meschia JF, Brott TG, Dickson DW, McKinney M: Aging blunts ischemic-preconditioning-induced neuroprotection following transient global ischemia in rats. Curr Neurovasc Res 2005, 2:365-374.

224. Della Morte D, Abete P, Gallucci F, Scaglione A, D'Ambrosio D, Gargiulo G, De Rosa G, Dave KR, Lin HW, Cacciatore F, Mazzella F, Uomo G, Rundek T, Perez-Pinzon MA, Rengo F: Transient ischemic attack before nonlacunar ischemic stroke in the elderly. J Stroke Cerebrovasc Dis 2008, 17:257-262.

225. Tomida S, Nowak TS Jr, Vass K, Lohr JM, Klatzo I: Experimental model for repetitive ischemic attacks in the gerbil: the cumulative effect of repeated ischemic insults. J Cereb Blood Flow Metab 1987, 7:773-782.

226. Pugliese AM, Latini S, Corradetti R, Pedata F: Brief, repeated, oxygenglucose deprivation episodes protect neurotransmission from a longer ischemic episode in the in vitro hippocampus: role of adenosine receptors. Br J Pharmacol 2003, 140:305-314.

227. Bigdeli MR, Hajizadeh S, Froozandeh M, Rasulian B, Heidarianpour A, Khoshbaten $A$ : Prolonged and intermittent normobaric hyperoxia induce different degrees of ischemic tolerance in rat brain tissue. Brain Res 2007, 1152:228-233.

228. Shen YT, Depre C, Yan L, Park JY, Tian B, Jain K, Chen L, Zhang Y, Kudej RK, Zhao X, Sadoshima J, Vatner DE, Vatner SF: Repetitive ischemia by coronary stenosis induces a novel window of ischemic preconditioning Circulation 2008, 118:1961-1969.

229. Ohno M, Watanabe S: Ischemic tolerance to memory impairment associated with hippocampal neuronal damage after transient cerebral ischemia in rats. Brain Res Bull 1996, 40:229-236.

230. Shamloo M, Wieloch T: Changes in protein tyrosine phosphorylation in the rat brain after cerebral ischemia in a model of ischemic tolerance. $J$ Cereb Blood Flow Metab 1999, 19:173-183.

231. Sommer C: Neuronal plasticity after ischemic preconditioning and TIAlike preconditioning ischemic periods. Acta Neuropathol 2009, 117:511-523.

232. Weih M, Kallenberg K, Bergk A, Dirnagl U, Harms L, Wernecke KD, Einhaupl KM: Attenuated stroke severity after prodromal TIA: a role for ischemic tolerance in the brain?. Stroke 1999, 30:1851-1854.

233. Schaller B: Ischemic preconditioning as induction of ischemic tolerance after transient ischemic attacks in human brain: its clinical relevance. Neurosci Lett 2005, 377:206-211.

234. Moncayo J, de Freitas GR, Bogousslavsky J, Altieri M, van Melle G: Do transient ischemic attacks have a neuroprotective effect?. Neurology 2000, 54:2089-2094.

235. Johnston SC: Ischemic preconditioning from transient ischemic attacks? Data from the Northern California TIA Study. Stroke 2004, 35:2680-2682.

236. Wegener S, Gottschalk B, Jovanovic V, Knab R, Fiebach JB, Schellinger PD, Kucinski T, Jungehulsing GJ, Brunecker P, Muller B, Banasik A, Amberger N,
Wernecke KD, Siebler M, Röther J, Villringer A, Weih M, MRI in Acute Stroke Study Group of the German Competence Network Stroke: Transient ischemic attacks before ischemic stroke: preconditioning the human brain? A multicenter magnetic resonance imaging study. Stroke 2004, 35:616-621.

237. Steiger HJ, Hanggi D: Ischaemic preconditioning of the brain, mechanisms and applications. Acta Neurochir (Wien) 2007, 149:1-10.

238. Caplan LR: Do transient ischemic attacks have a neuroprotective effect? Neurology 2000, 55:1596.

239. Dirnagl U, Becker $K$, Meisel A: Preconditioning and tolerance against cerebral ischaemia: from experimental strategies to clinical use. Lancet Neurol 2009, 8:398-412.

240. Castillo J, Moro MA, Blanco M, Leira R, Serena J, Lizasoain I, Davalos A: The release of tumor necrosis factor-alpha is associated with ischemic tolerance in human stroke. Ann Neurol 2003, 54:811-819.

241. Laskey WK, Beach D: Frequency and clinical significance of ischemic preconditioning during percutaneous coronary intervention. J Am Coll Cardiol 2003, 42:998-1003.

242. Ineid H, Leessar M, Bolli R: Cardiac preconditioning during percutaneous coronary interventions. Cardiovasc Drugs Ther 2005, 19:211-217.

doi:10.1186/2040-7378-2-2

Cite this article as: Durukan and Tatlisumak: Preconditioning-induced ischemic tolerance:

a window into endogenous gearing for cerebroprotection. Experimental \& Translational Stroke Medicine 2010 2:2.

\section{Submit your next manuscript to BioMed Central and take full advantage of:}

- Convenient online submission

- Thorough peer review

- No space constraints or color figure charges

- Immediate publication on acceptance

- Inclusion in PubMed, CAS, Scopus and Google Scholar

- Research which is freely available for redistribution

Submit your manuscript at www.biomedcentral.com/submit
C Biomed Central 